\title{
Linking horizontal and vertical transports of biomass fire emissions to the tropical Atlantic ozone paradox during the Northern Hemisphere winter season: climatology
}

\author{
G. S. Jenkins and J.-H. Ryu \\ Department of Meteorology, Penn State University, 503 Walker Building, University Park, Pennsylvania, USA
}

Received: 29 July 2003 - Published in Atmos. Chem. Phys. Discuss.: 13 October 2003

Revised: 22 December 2003 - Accepted: 22 December 2003 - Published: 22 March 2004

\begin{abstract}
During the Northern hemisphere winter season, biomass burning is widespread in West Africa, yet the total tropospheric column ozone values $(<30 \mathrm{DU})$ over much of the Tropical Atlantic Ocean $\left(15^{\circ} \mathrm{N}-5^{\circ} \mathrm{S}\right)$ are relatively low. At the same time, the tropospheric column ozone values in the Southern Tropical Atlantic are higher than those in the Northern Hemisphere (ozone paradox). We examine the causes for low tropospheric column ozone values by considering the horizontal and vertical transport of biomass fire emissions in West Africa during November through March, using observed data which characterizes fires, aerosols, horizontal winds, precipitation, lightning and outgoing longwave radiation. We have found that easterly winds prevail in the lower troposphere but transition to westerly winds at pressure levels lower than $500 \mathrm{hPa}$. A persistent anticyclone over West Africa at $700 \mathrm{hPa}$ is responsible for strong easterly winds, which causes a net outflow of ozone/ozone precursors from biomass burning in West Africa across the Atlantic Ocean towards South America. The lowest outgoing longwave radiation (OLR) and highest precipitation rates are generally found over the central Atlantic, some distance downstream of fires in West Africa making the vertical transport of ozone and ozone precursors less likely and ozone destruction more likely. However, lightning over land areas in Central Africa and South America can lead to enhanced ozone levels in the upper troposphere especially over the Southern tropical Atlantic during the Northern Hemisphere winter season.
\end{abstract}

\section{Introduction}

Biomass burning in the tropics serves as a primary source for atmospheric pollutants on an annual basis. In the early 1990 s, it was estimated that the global annual biomass burning represented 1.8 of the $4.7 \mathrm{GT}$ of carbon burned and re-

Correspondence to: G. S. Jenkins

(osei@essc.psu.edu) leased to the atmosphere, with the savanna fires being the dominant component (1-1.6 GT of carbon burned) (Crutzen and Carmichael, 1993). Moreover, African savanna fires are estimated to account for $30 \%$ of the global biomass burning emissions of trace gas and aerosols (Lacaux et al., 1993). The source of savanna fires in Africa are not centrally located in one area but can be found in the Northern and Southern Hemisphere during various times of the year. In addition, savanna fires can be found in both western and eastern parts of Africa (Jenkins et al., 1997). The majority of fires are associated with clearing of forest, agricultural use, control of weeds and brush and nutrient regeneration in grazing and crop-lands (Andreae, 1991).

Biomass burning is a source of carbon monoxide oxidation which in the presence of nitrogen oxide ( $>4$ pptv) can lead to ozone production in the tropics. Marufu et al. (2000) estimate that biomass burning emissions contribute $9 \%$ to the production of global tropospheric ozone on annual timescales. Africa represents the largest contribution to the production of tropospheric ozone accounting for approximately $35 \%$ of the total. In addition to being a pollutant in the planetary boundary layer (PBL), $\mathrm{O}_{3}$ in the troposphere acts as a greenhouse gas, increasing the longwave forcing directed towards the surface. The formation of ozone near the source of the fires in the planetary boundary layer (PBL) can influence the health of individuals near the fires but is quickly destroyed through deposition and photolysis. However, if ozone and its precursors $(\mathrm{CO}, \mathrm{NO})$ can be vertically transported above the PBL, then the lifetime of ozone can increase from days to weeks. Satellite estimates of tropospheric column ozone (TCO) values associated with biomass burning show the highest levels over the Tropical Atlantic during the months of August through November (Fishman et al. 1991). Field experiments with measurements over the Tropical Atlantic and adjacent land areas in South America (TRACE-A) and Southern Africa (SAFARI) have been carried out in order to understand the relationship between biomass burning and 
Ozone (Dobson units) : 1979-1992
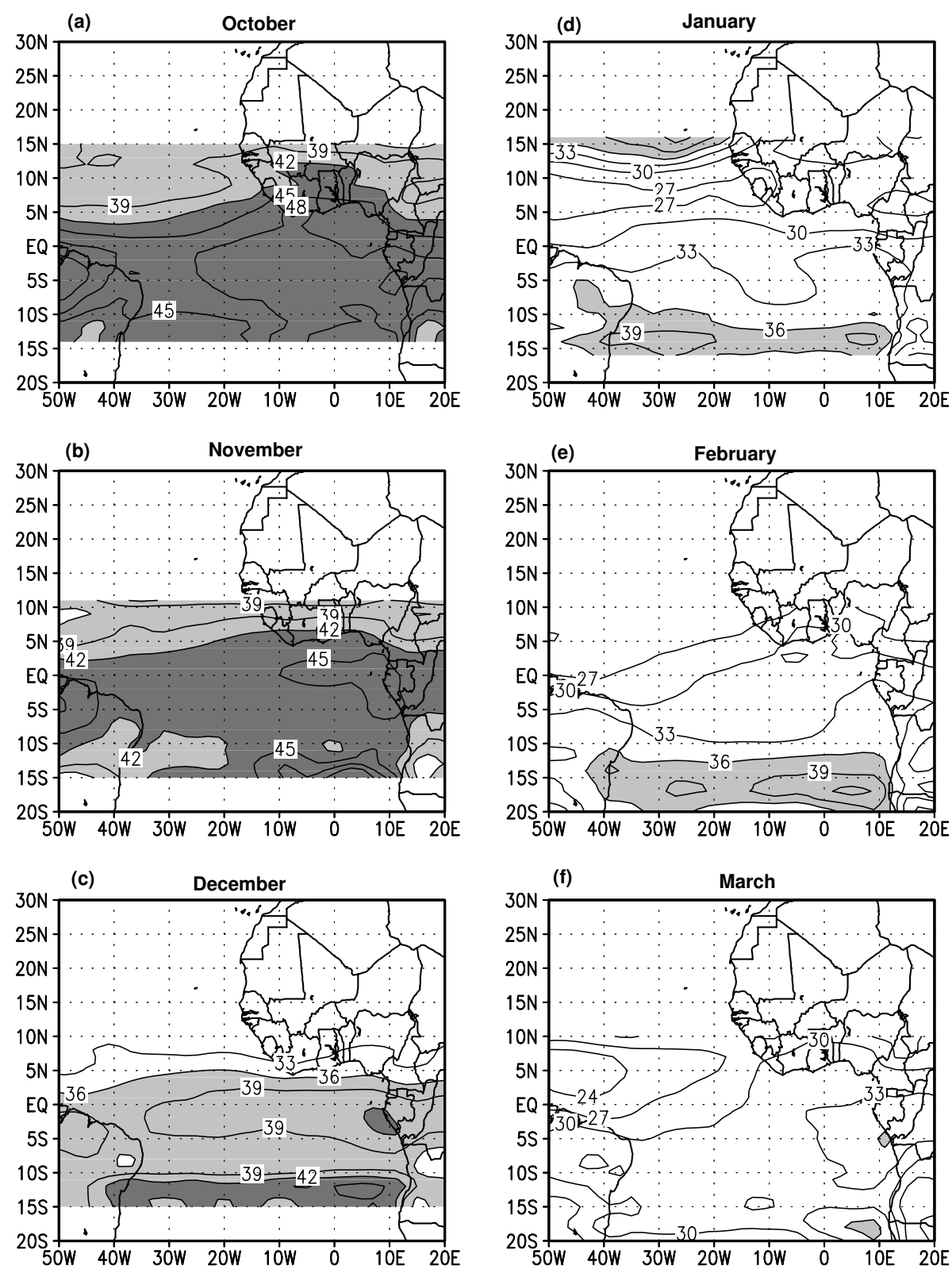

Fig. 1. The spatial distribution of TOMS tropospheric column ozone values (Dobson unit) during (a) October through (f) March averaged from 1979 to 1992 .

elevated tropospheric ozone (Fishman et al., 1996; Lindesay et al., 1996).

During the Northern Hemisphere winter season, biomass burning is found north of the Equator $\left(\sim 5-15^{\circ} \mathrm{N}\right.$ ) (Grégoire et al., 1999). However, satellite and ozonesonde estimates of tropospheric column ozone show lower values over the north Tropical Atlantic Ocean relative to the south Tropical Atlantic and is denoted as the "Ozone Paradox" (Weller et al., 1996; Thompson et al., 2000). This suggests there might be several processes at work with respect to reduced tro- pospheric columnar ozone in the Northern Hemisphere: (1) Ozone is produced near areas of biomass burning but limited to the PBL and destroyed in time ( $<1$ week) by deposition and photolysis. (2) An important $\mathrm{O}_{3}$ precursor is not found in sufficient quantities for the production of $\mathrm{O}_{3}$. The most likely $\mathrm{O}_{3}$ precursor that would limit $\mathrm{O}_{3}$ production is NO. In such a case $\mathrm{HO}_{2}$ could lead to the destruction of $\mathrm{O}_{3}$. However, measurements in TROPOZ I and II show that NO is produced in sufficient quantities near areas of biomass burning contributing to the production of $\mathrm{O}_{3}$ (Jonquieres et al., 1998). 
(3) $\mathrm{O}_{3}$ is produced in the PBL and vertically transported into the free troposphere. It is then transported horizontally to other regions by mean winds in the middle or upper troposphere.

Measurements from aircraft, ship, and ozonesondes show elevated ozone mixing ratios in the lower troposphere (3$5 \mathrm{~km})$ over the Tropical Atlantic Ocean downstream of biomass burning in West Africa (Jonquieres et al., 1998; Thompson, et al., 2000). Jonquieres et al. (1998) suggests that $\mathrm{O}_{3}$ is produced over West Africa and is transported at low altitudes ( $3-5 \mathrm{~km}$ above the surface) by easterly winds towards South America. Both TROPOZ and AEROSOLS99 also found elevated levels of ozone in the middle and upper troposphere over the Southern Tropical Atlantic. Thompson et al. (2000) suggest that these elevated levels of ozone in the middle/upper troposphere were due to either a mid-latitude source or lightning, depending on the latitude. Edwards et al. (2003) have reached a similar conclusion to Thompson et al. (2000) from their satellite study during January 2001. However, these studies covered relatively short periods of time (several weeks). In this study, observational data sets are averaged over numerous seasons in order to produce a climatology.

Meteorological conditions during the winter and spring seasons, which are important to the horizontal and vertical transports of biomass fire emission, are controlled by dry northeasterly Harmattan winds with the Sahara Desert origin from the surface into the lower troposphere. Near the Guinea coastline, a layer of moist southwesterly winds blow from the Gulf of Guinea and there is precipitation over extreme southern parts of West Africa. If vertical transport were to occur it should be due to the convection (shallow or deep). Jonquieres et al. (1998) suggest that dry Harmattan winds carry $\mathrm{O}_{3}$ and $\mathrm{O}_{3}$ precursors above the Monsoon layer as seen through cross sections of equivalent potential temperature between $5^{\circ} \mathrm{S}$ and $5^{\circ} \mathrm{N}$.

The objectives of this study are to examine: (1) the horizontal transport of biomass fire emissions from West Africa during the Northern Hemisphere winter season. (2) Examine mechanisms for the vertical transport of biomass fire emissions. (3) Examine lightning over the continental outflow of South America and Central Africa during Northern Hemisphere winter. (4) To relate biomass emission, transport and lightning to the satellite observations of relatively low (high) tropospheric column ozone levels over the Northern (Southern) Tropical Atlantic during the Northern Hemisphere winter ("ozone paradox"). This paper focuses on a climatological time-scale (1979-1992) during the Northern Hemisphere winter season (DJF), while a companion paper examines objectives 1 to 4 on daily time-scales during the Aerosols99 ship campaign (Jenkins et al., 2003).

\section{Data description}

Ozone, wind, precipitation and OLR are averaged for the period of 1979-1992 in order to establish climatological conditions near West Africa. The National Center for Environmental Prediction (NCEP) reanalysis (Kalnay et al., 1996) averaged for January 1979-1992 are used at a horizontal resolution of $2.5^{\circ} \times 2.5^{\circ}$. The rain rates are derived from a merged data set using satellite and rain gauge data and produced at a horizontal resolution of $2.5^{\circ} \times 2.5^{\circ}$ (Xie and Arkin, 1997). The ozone climatology (1979-1992) produced from the total ozone mapping spectrometer (TOMS) is produced at a horizontal resolution of $1^{\circ} \times 2^{\circ}$ (Hudson and Thompson, 1998; Thompson and Hudson, 1999). Additional data associated with the production of ozone (fire counts, aerosols and lightning) are also used here but do not overlap with the meteorological and ozone data. The ozone vertical profiles from Southern Hemisphere Additional Ozonesondes (SHADOZ) stations are also used for 1998-2000 (Thompson et al., 2003). The fire count data (1996-1999) is produced from the Along Tracking Scanning Radiometer (ATSR) instrument, which has a horizontal resolution of $1 \mathrm{~km}$ and a swath width of $512 \mathrm{~km}$. Fires are identified at a fixed threshold of $312^{\circ} \mathrm{K}$ (Arino and Melinotte, 1995). Fires tend to be underestimated by the ATSR instrument because of its relatively poor temporal resolution with the satellite visiting a site once every three days in equatorial regions (Buongiorno et al., 1997). The 1996-1999 monthly aerosol index is produced on a $1^{\circ} \times 1.25^{\circ}$ grid with a minimum of 20 days necessary to produce a monthly average (Herman et al., 1997; Torres et al., 1998). The Lightning Imaging Sensor (LIS)/Optical Transient Detector (OTD) $2.5^{\circ}$ low-resolution annual climatology is used for lightning data. This climatology is a combination of the 5-yr OTD (4/1995-3/2000) and 3 -yr LIS (12/1997-11/2000) data and has been averaged for 2 months to reduced the bias due to undersampling (Williams et al., 2000; Christian et al., 2003). Non-gridded monthly Lightning flashes from daily LIS overpasses are also used in this study.

\section{Result}

\subsection{Fire counts and aerosol indices}

Figure 1 shows the time-averaged 1979-1992 tropospheric column ozone values for October through March over West Africa and the adjacent Tropical Atlantic Ocean. High tropospheric ozone columnar values ( $>42 \mathrm{DU}$ ) can be found during October and November in association with the Tropical Atlantic ozone maximum (Fishman et al., 1991). Thereafter, smaller ozone values ( $<30 \mathrm{DU})$ are found over the tropical Atlantic and adjacent West Africa. During January and February, less than 36DU can be found over much of the tropical Atlantic, especially those areas adjacent 
(a)

Average Fire Count in West Africa (5-15N, 15W-25E)

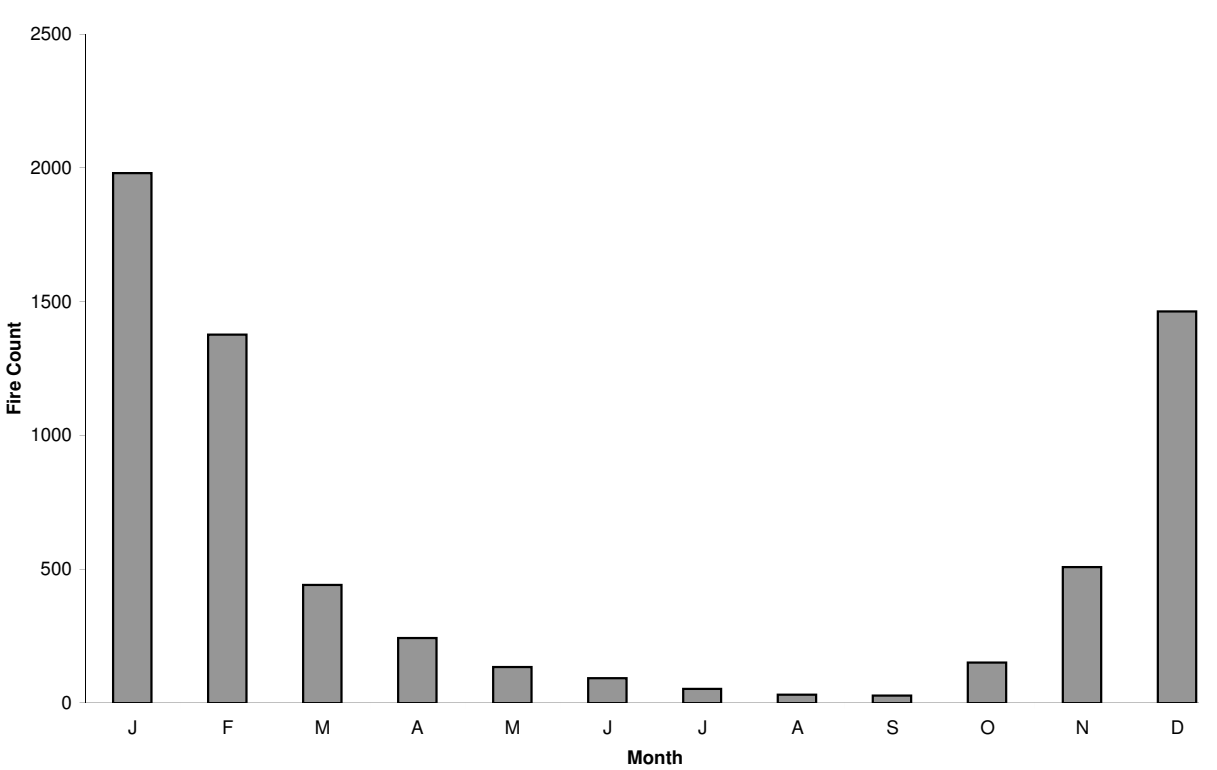

(b)

Aerosol Index (5-15N, $15 \quad$ W-25E) - Land

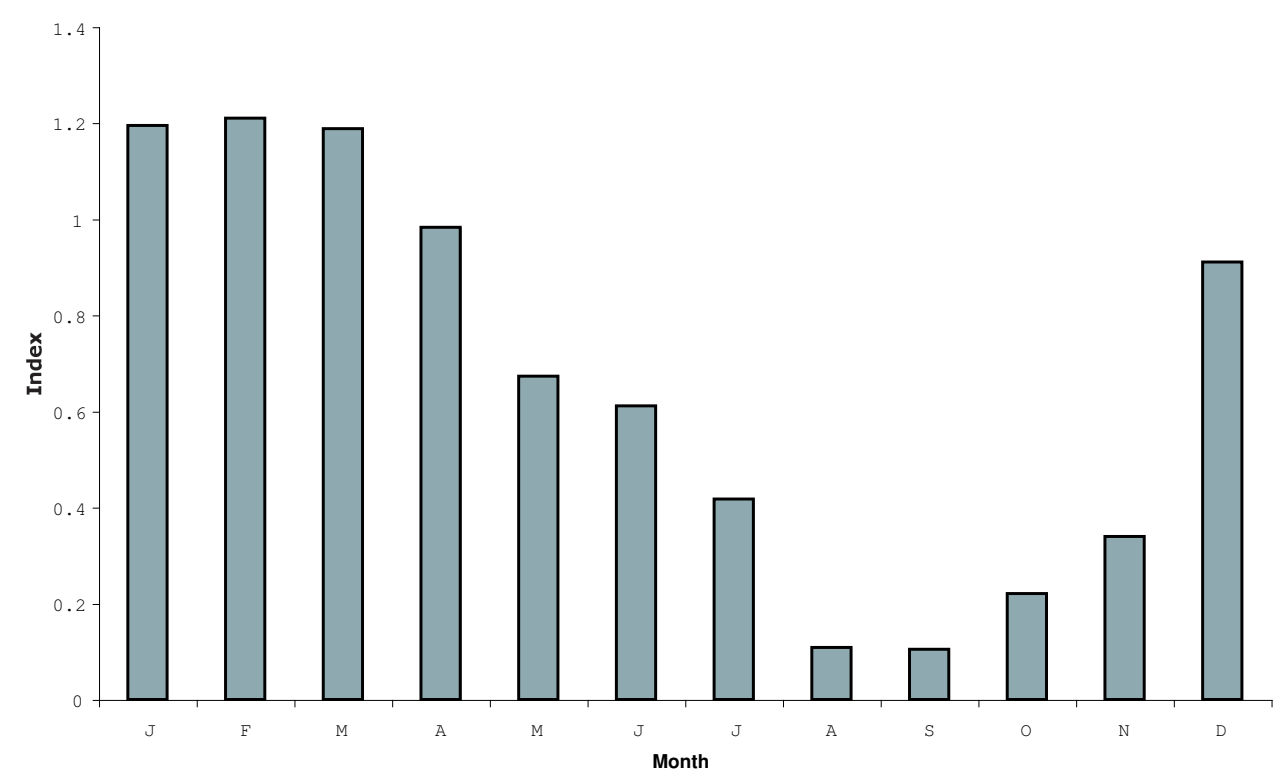

Fig. 2. (a) The monthly fire count in West Africa $\left(5^{\circ} \mathrm{N}-15^{\circ} \mathrm{N}, 15^{\circ} \mathrm{W}-25^{\circ} \mathrm{E}\right)$, (b) the aerosol index over land $\left(5^{\circ} \mathrm{N}-15^{\circ} \mathrm{N}, 15^{\circ} \mathrm{W}-25^{\circ} \mathrm{E}\right)$ averaged from 1996 to 1999.

to West Africa. Higher values of ozone are found between $10^{\circ} \mathrm{S}$ to $15^{\circ} \mathrm{S}$ during January and February. A similar pattern of low tropospheric columnar ozone values is found using the cloud-slicing method of Ziemke et al. (2001) (http://code916.gsfc.nasa.gov/Data_services/ cloud-slice/gif/clim79-01seas.gif). January ship measure- ments of Weller et al. (1996), Thompson et al. (2000), and aircraft measurements in January (Martin et al., 2002) show that the highest ozone mixing ratios are found lower troposphere. The climatological tropospheric column ozone values shown in Fig. 1 during January over West Africa and the adjacent Atlantic Ocean are slightly lower than those 

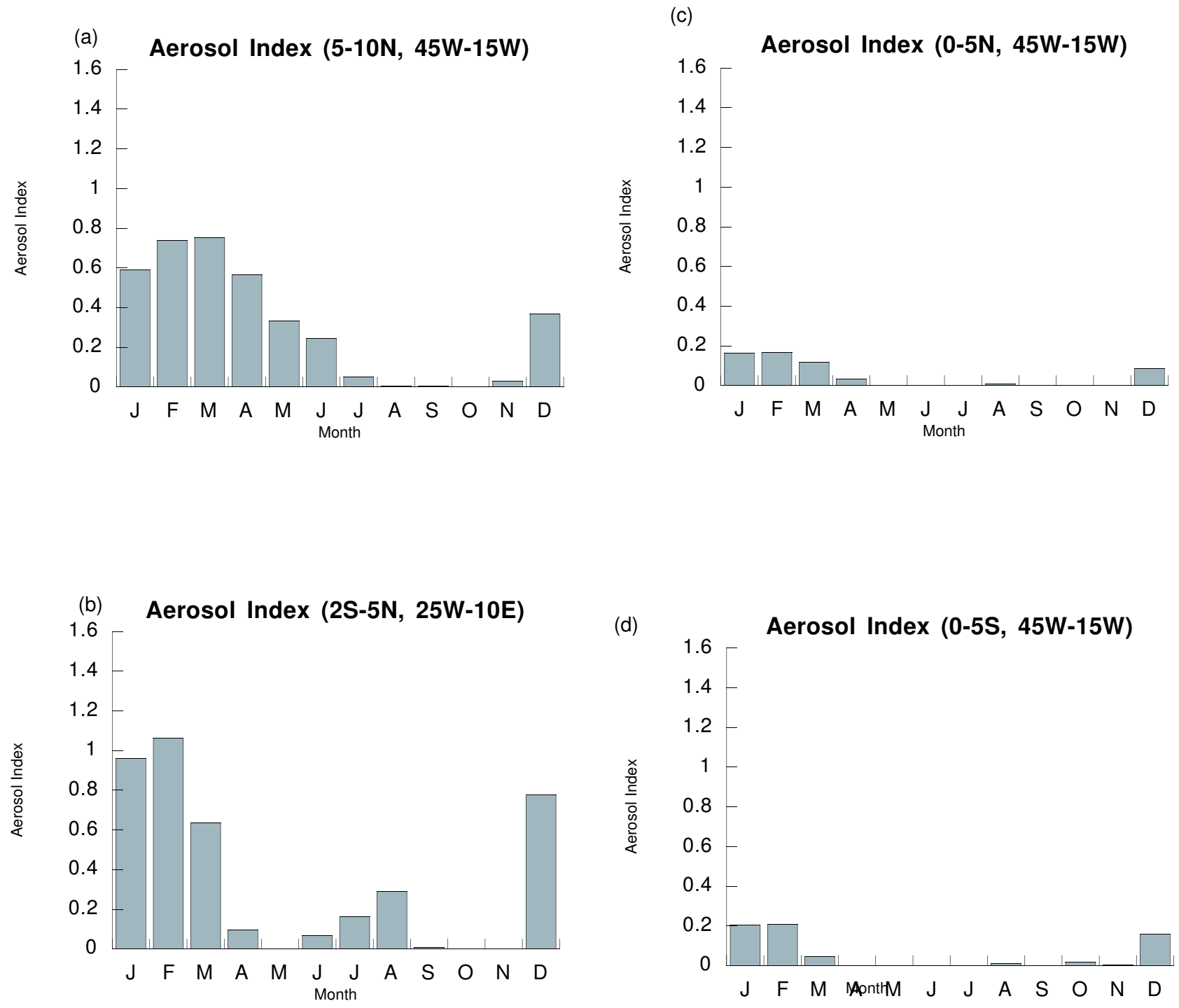

Fig. 3. The monthly aerosol index averaged over the area of (a) $5^{\circ}-10^{\circ} \mathrm{N}, 45^{\circ} \mathrm{W}-15^{\circ} \mathrm{W}$, (b) $2^{\circ} \mathrm{S}-5^{\circ} \mathrm{N}, 25^{\circ} \mathrm{W}-10^{\circ} \mathrm{E},(\mathbf{c}) 0^{\circ}-5^{\circ} \mathrm{N}, 45^{\circ} \mathrm{W}-$ $15^{\circ} \mathrm{W}$, (d) $0^{\circ}-5^{\circ} \mathrm{S}, 45^{\circ} \mathrm{W}-15^{\circ} \mathrm{W}$.

found during January 1999 (Thompson et al., 2000) and January 2001 (Edwards et al., 2003) with the overall pattern being quiet similar. However, Kim et al. (2001) suggest that TOMS can underestimate the tropospheric column ozone if high ozone mixing ratios are found in the lower troposphere. Martin et al. (2002) suggest that TOMS tropospheric column ozone values are underestimated by 3-5 DU during DJF over areas of biomass burning in West Africa because biomass burning is confined to the lower troposphere. There are also other factors such as clouds, dust and aerosols that can influence tropospheric column ozone values (Edwards et al., 2003).

The low tropospheric column ozone values in Fig. 1 occur during the period (January, February) when the number of fires and aerosol indices in West Africa obtain their highest values (Fig. 2). The fire count in West Africa $\left(5^{\circ}-\right.$ $15^{\circ} \mathrm{N}, 15^{\circ} \mathrm{W}-25^{\circ} \mathrm{E}$ ) is averaged from 1996 to December 1999. Monthly geographic distributions of biomass burning can be obtained from (http://shark1.esrin.esa.it/ionia/FIRE/ AF/ATSR.). The fires occur primarily during Northern Hemispheric winter increasing after the month of November, peaking in January and declining thereafter (Fig. 2a). Figure $2 b$ shows the aerosol index over a large portion of West Africa $\left(5-15^{\circ} \mathrm{N}, 15^{\circ} \mathrm{W}-25^{\circ} \mathrm{E}\right)$. The aerosol index also has a maximum during winter and high values persist for several months after the highest frequency of detected fires. High aerosol indices are found during March and April when the fire counts have fallen considerably. This suggests that aerosols can remain suspended over West Africa even when fire counts are lower. 
(a) November 96-99 Aerosol index

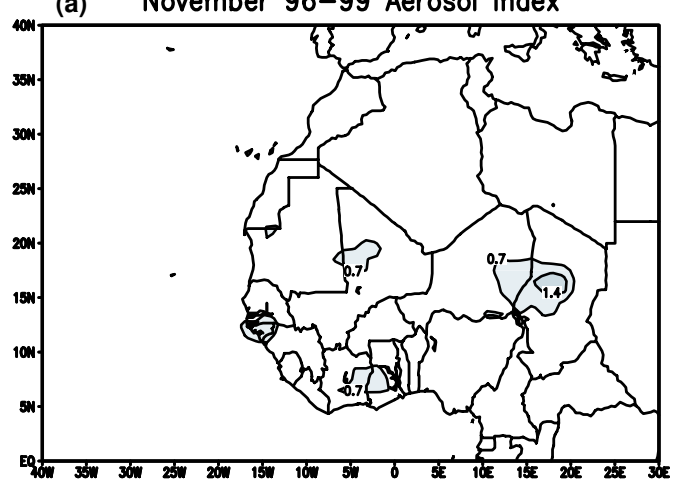

(b) December 96-99 Aerosol index

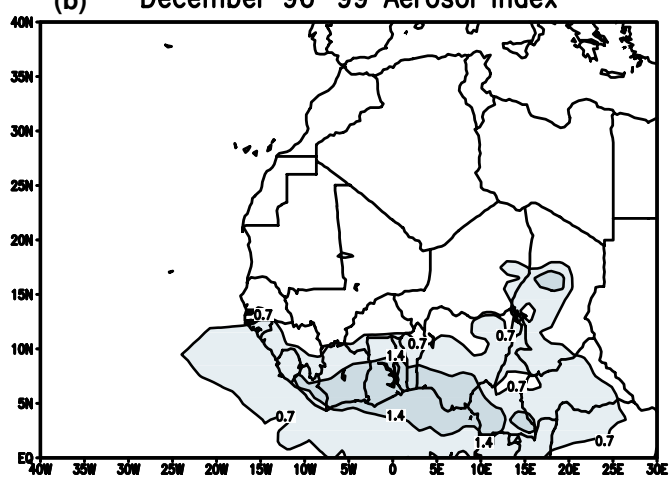

(d) February 97-99 Aerosol index
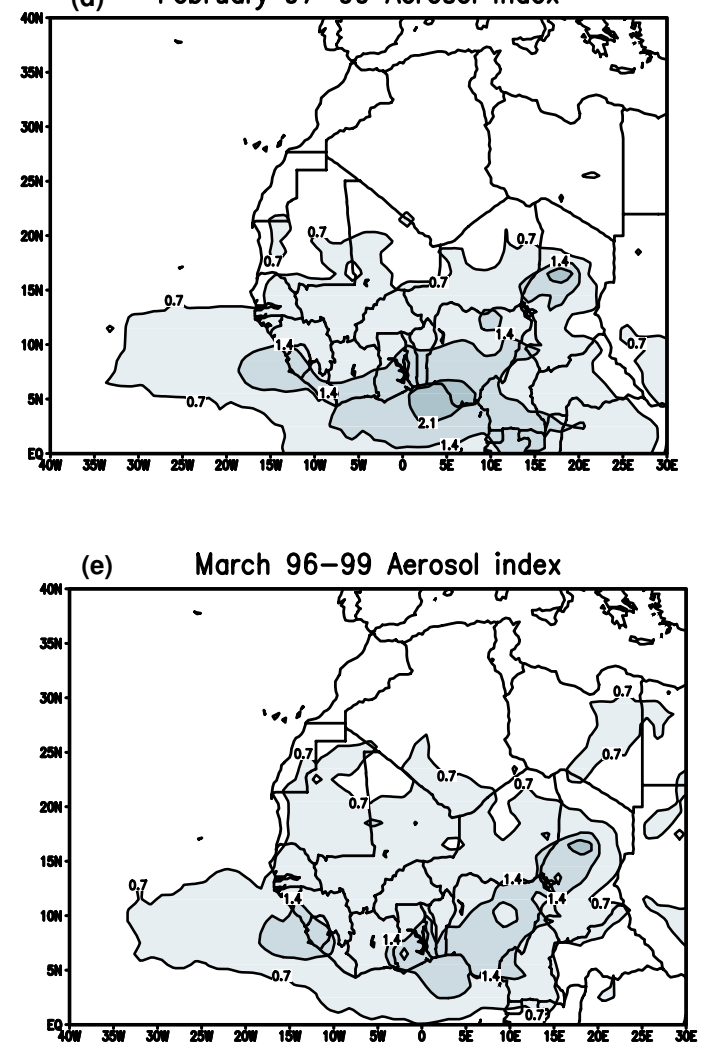

(c) January 97-99 Aerosol index

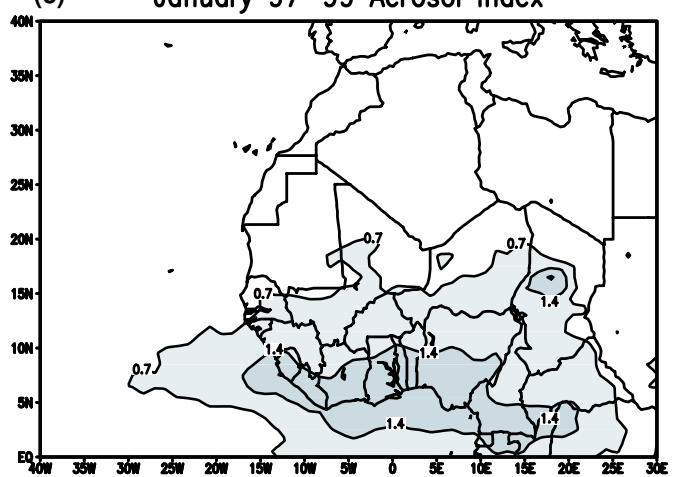

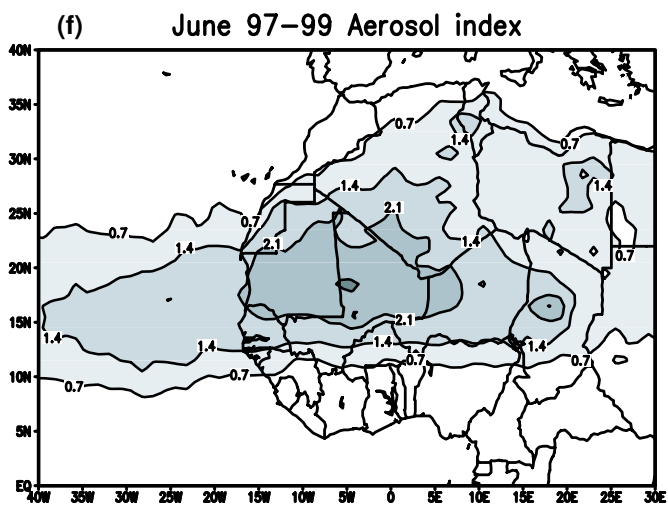

$\begin{array}{lllll}0.7 & 1.4 & 2.1 & 2.8 & 3.5\end{array}$

Fig. 4. The spatial distribution of the aerosol index in West Africa during (a) November through (e) March and (f) June.

In the examination of aerosol indices for ocean areas adjacent to West Africa, the highest aerosol indices are found from January through March. There are two notable areas where high aerosol index values are found: to the west of the continent in the latitudes of $5-10^{\circ} \mathrm{N}$ (Fig. 3a) and just to the south of land areas over the Gulf of Guinea, between $2^{\circ} \mathrm{S}$ and $5^{\circ} \mathrm{N}$ (Fig. 3b). The result suggests that two exit regions for constituents from biomass burning - to the west and to the south. Figure 3 a shows the aerosol index averaged over the ocean $\left(5-10^{\circ} \mathrm{N}, 45^{\circ} \mathrm{W}-15^{\circ} \mathrm{W}\right)$. The aerosol indices here are approximately $1 / 2$ of the land values due to scavenging by precipitation and gravity (Fig. 2b) and possess a similar temporal pattern. Figure $3 \mathrm{~b}$ shows that the highest ocean aerosol indices occur just south of the West African land mass $\left(2^{\circ} \mathrm{S}-\right.$ $\left.5^{\circ} \mathrm{N}, 25^{\circ} \mathrm{E}-10^{\circ} \mathrm{W}\right)$. The aerosol indices over this region correspond closely to those over land areas (Fig. 2b) implying constituents from biomass burning are transported into this region from land. To areas just north and south of the Equator 

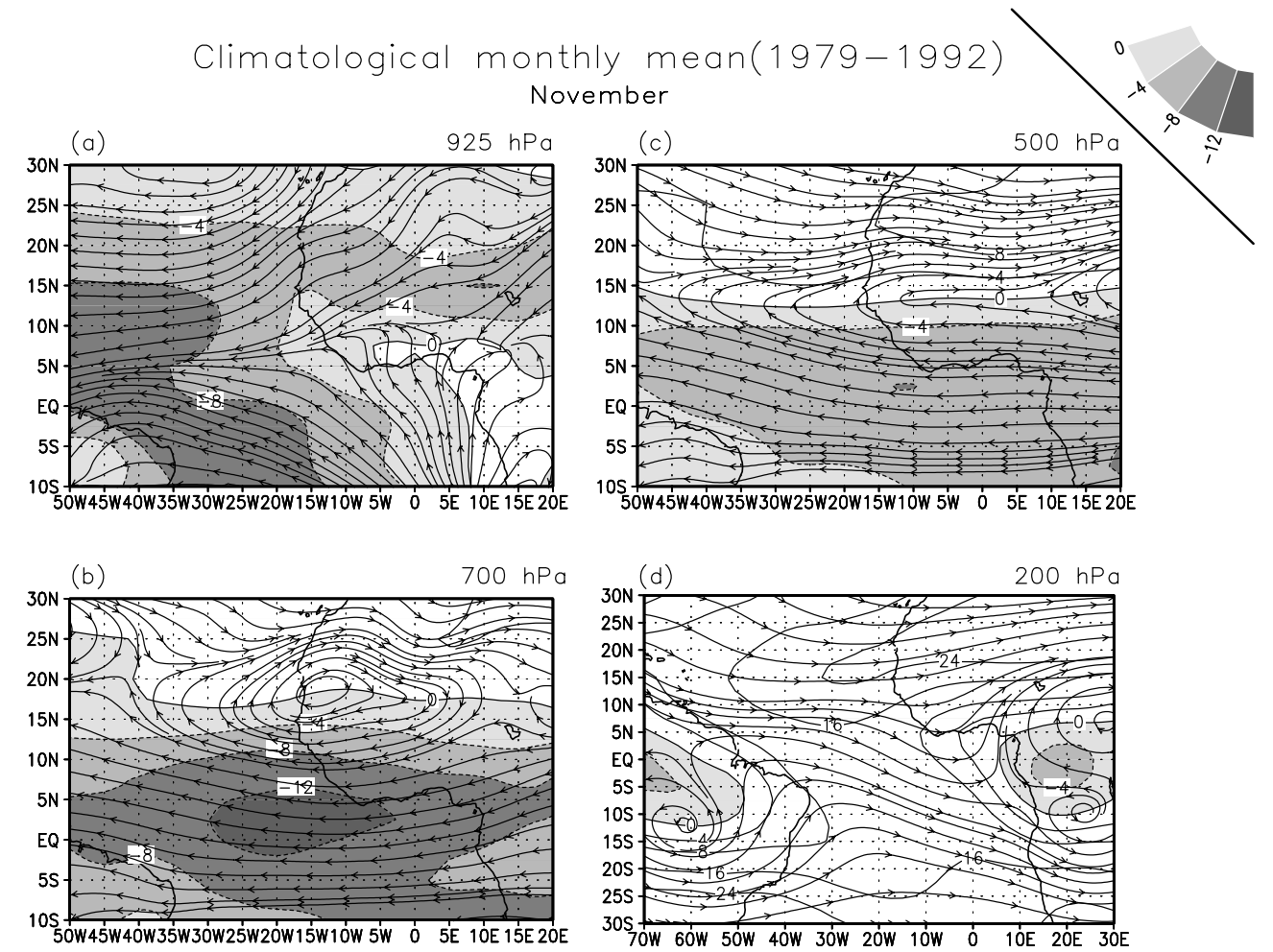

Fig. 5. The climatology of the zonal wind and streamlines in West Africa at (a) $925 \mathrm{hPa}$, (b) $700 \mathrm{hPa}$, (c) $500 \mathrm{hPa}$ and (d) $200 \mathrm{hPa}$ for November averaged from 1979 to 1992.
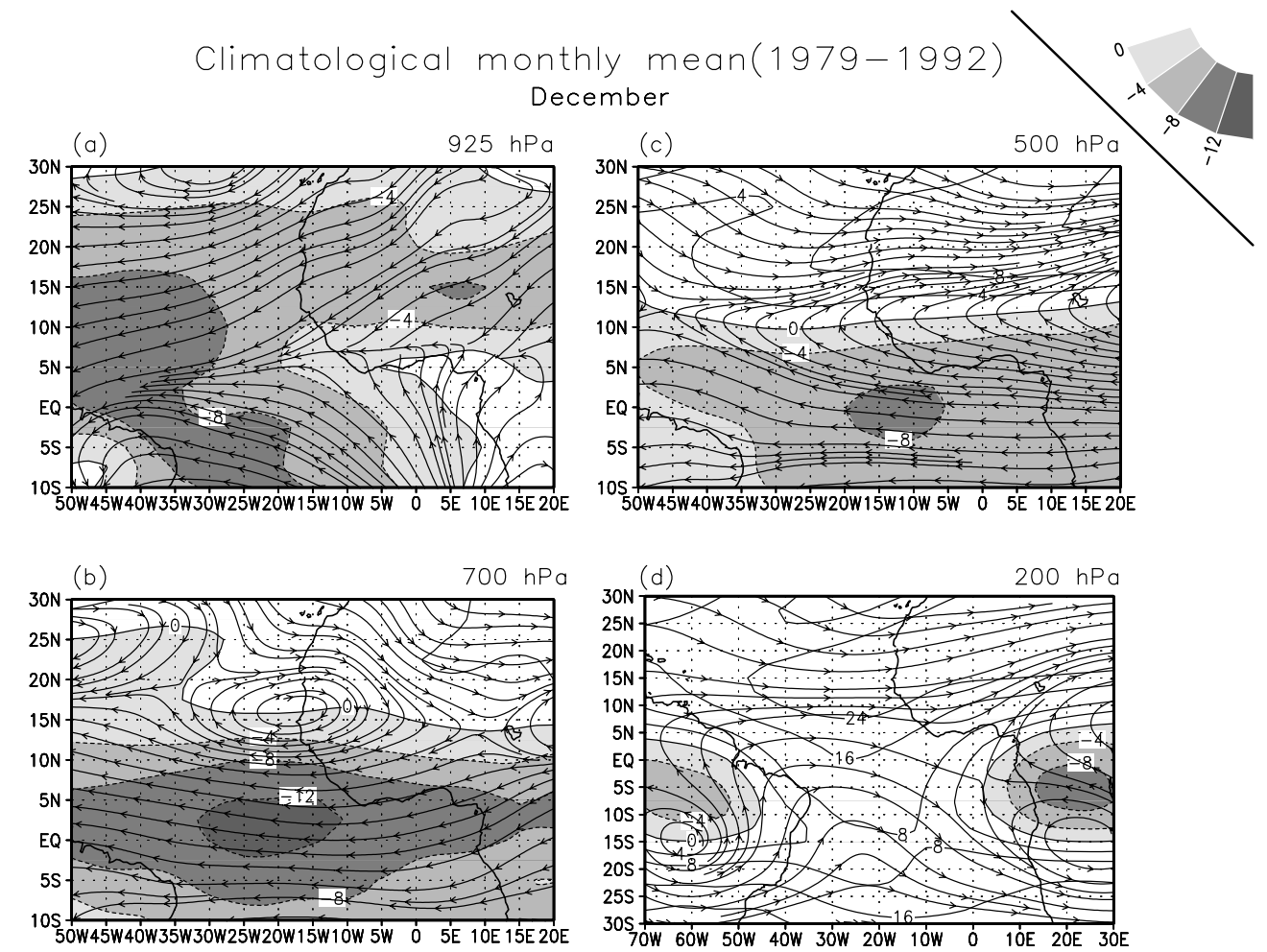

Fig. 6. Same as Fig. 5 except December. 


$$
\text { Climatological monthly mean(1979-1992) }
$$
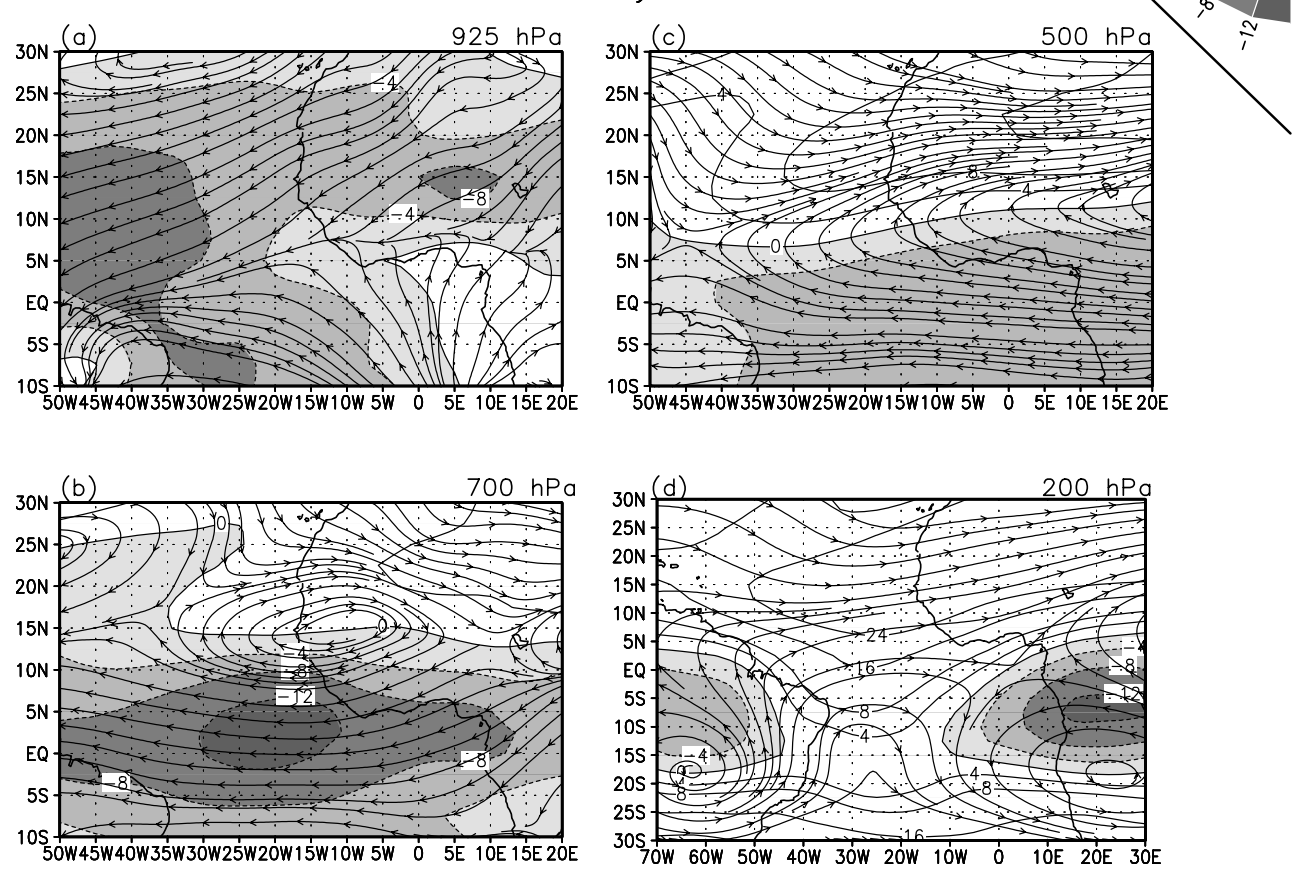

Fig. 7. Same as Fig. 5 except January.
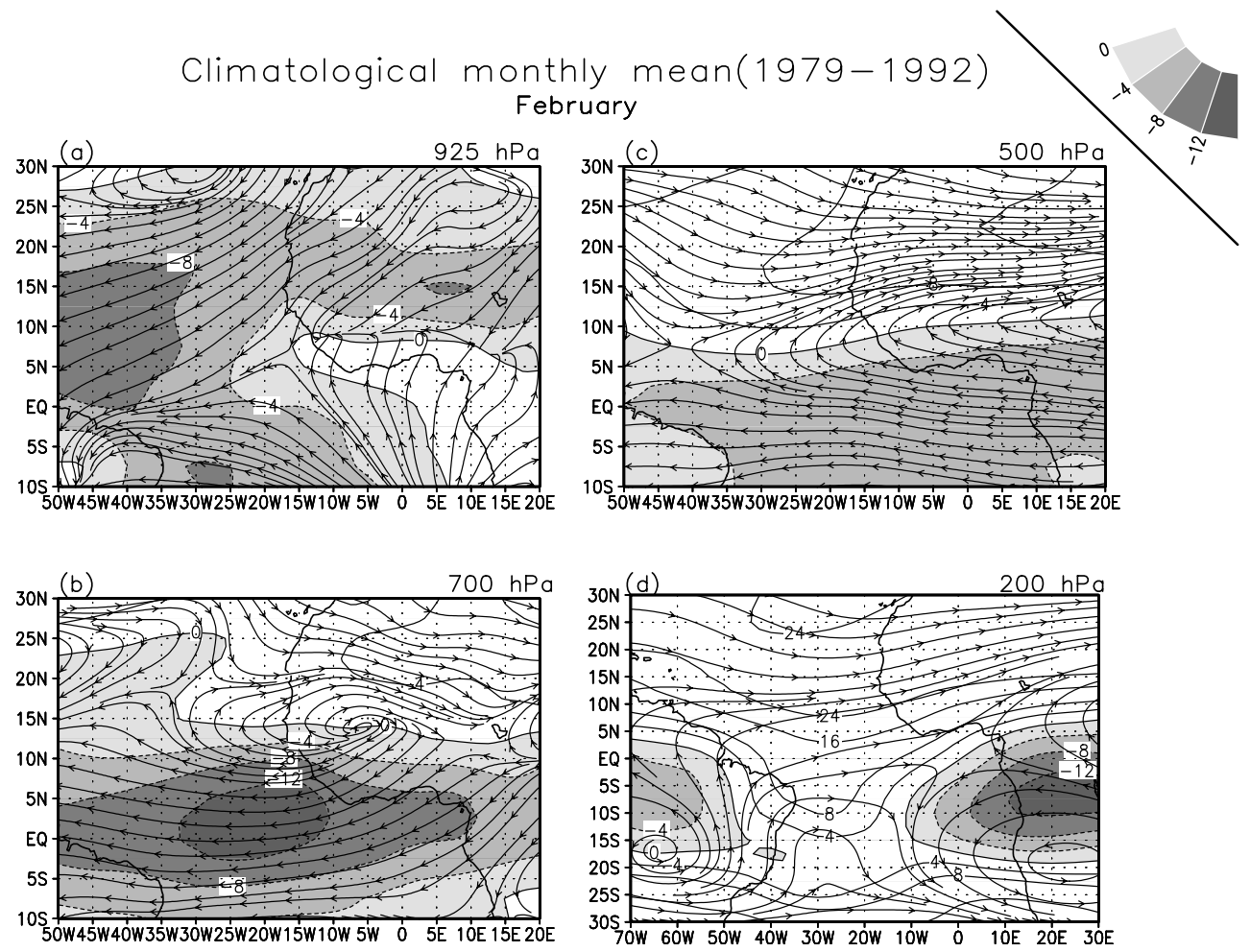

Fig. 8. Same as Fig. 5 except February. 
and located further downstream, the highest aerosol indices occur during December, January and February but the values are considerably reduced relative to land values and ocean areas closer to the West African land mass (Figs. 3c, 3d).

Figures $4 \mathrm{a}-\mathrm{f}$ show the spatial distribution of aerosols for November through March and June averaged from 1996 to 1999. The aerosols can be seen in several isolated regions in November. It is during December, January and February when the fires occur in West Africa that high index values can be seen in the latitudes of $5-10^{\circ} \mathrm{N}$, extending over ocean areas due south and west of land areas. The highest indices over the ocean are confined to areas just north of the Equator and to the east of $30^{\circ} \mathrm{W}$. The location of the high aerosol index values corresponds to areas of fires, implying that the detected aerosols are due to biomass burning and not Saharan dust. During the month of March, high aerosol indices are found even when the fire count is substantially lower (Fig. 4e). The high aerosol indices could be due to a combination of mineral dust and carbonaceous aerosols from smoldering fires that have not been detected by satellite. March marks the end of the dry season in extreme southern parts of West Africa as precipitation begins to return. However by June, when the detected fire counts are low, high aerosol indices are due to Saharan dust, where high values are found to stretch across the Atlantic Ocean poleward of $10^{\circ} \mathrm{N}$ (Fig. 4f).

\subsection{Horizontal transport processes}

Figures 5-8 show the November through February timeaveraged 1979-1992 zonal wind and streamlines at $925 \mathrm{hPa}$, $700 \mathrm{hPa}, 500 \mathrm{hPa}$ and $200 \mathrm{hPa}$ levels over West Africa and the adjacent Atlantic Ocean. At $925 \mathrm{hPa}$, winds are directed from the northeast and converge with southerly flow at approximately $5^{\circ} \mathrm{N}$ during November and February but converge at slightly lower latitudes during December and January (Figs. 5a, 6a, 7a, 8a). Hence, $\mathrm{O}_{3}, \mathrm{O}_{3}$ precursors and aerosols associated with savanna fires would be transported equatorward towards the convergence zone during these months as noted by Jonquieres et al. (1998). Over the Atlantic Ocean, the easterly winds are dominant during this period. A characteristic feature at $700 \mathrm{hPa}$ is an anticyclone centered near $15^{\circ} \mathrm{N}$ in the longitude range of $20^{\circ} \mathrm{W}-10^{\circ} \mathrm{W}$ which persists from November through February (Figs. 5b, $6 \mathrm{~b}, 7 \mathrm{~b}, 8 \mathrm{~b})$. Westerly winds can be found to the north of the anticyclone and easterly winds to the south of it. The strongest easterly winds are found over the Eastern Atlantic between the Equator and $5^{\circ} \mathrm{N}$ and longitudes of $15-30^{\circ} \mathrm{W}$. This is not the West African Easterly Jet (AEJ) as suggested by Jonquieres et al. (1998) that owes its existence primarily to the meridional temperature gradient over land areas of West Africa (Cooke, 1999). The AEJ is found during the months of May through October and extends from Lake Chad out to the Eastern Atlantic Ocean. Finally, the AEJ is generally found between $8^{\circ} \mathrm{N}$ and $16^{\circ} \mathrm{N}$ while the strong east- erly winds identified by Jonquieres et al. (1998) are found at lower latitudes and located further west during January.

Anti-cyclonic circulation is also found at $500 \mathrm{hPa}$ with the axis of the anticyclone found in the latitudes of $5-15^{\circ} \mathrm{N}$ during the period (Figs. 5c, 6c, 7c, 8c). To the south of the axis, easterly winds are found to extend as far north as $10^{\circ} \mathrm{N}$ during November but are confined to lower latitudes during December, January and February. The winds at $500 \mathrm{hPa}$ are weaker than those at $700 \mathrm{hPa}$ during the time period. This circulation at $500 \mathrm{hPa}$ is persistent through February and westerly winds intensify over Northern Africa. A transition to westerly winds occurs at approximately $300 \mathrm{hPa}$ and prevailing winds are from the west or southwest directions throughout the tropics at $200 \mathrm{hPa}$ throughout the period (Figs. $5 \mathrm{~d}, 6 \mathrm{~d}$, $7 \mathrm{~d}, 8 \mathrm{~d})$. The strongest westerly winds $(>24 \mathrm{~m} / \mathrm{s})$ over West Africa are found during January and February.

A north-south vertical profile of zonal winds at $10^{\circ} \mathrm{W}$ from October through March (Fig. 9a-f) shows that easterly winds are found throughout the lower and middle troposphere. The core of easterly winds is centered at near $700 \mathrm{hPa}$ from October through March and its latitudinal position is located between $5^{\circ} \mathrm{S}-15^{\circ} \mathrm{N}$. There is a transition, however, from easterly to westerly winds at approximately $500 \mathrm{hPa}$ at $10^{\circ} \mathrm{N}$. Equatorward of $10^{\circ} \mathrm{N}$, this transition takes place at lower pressure levels (higher altitudes) but poleward of $10^{\circ} \mathrm{N}$ this transition occurs at higher pressure levels (lower altitudes) between $600-700 \mathrm{hPa}$. This zonal wind profile implies that convection would not extend to very high altitudes and would be confined to the middle troposphere where the convective systems would be embedded in the easterly flow. Organized convective systems would encounter a significant amount of vertical shear in areas to the north of $10^{\circ} \mathrm{N}$ and therefore would not be long-lived systems. But organized convective systems are a rarity poleward of $10^{\circ} \mathrm{N}$ from November through March as the "dry season" has commenced in West Africa.

\subsection{Vertical transport processes}

Low OLR fluxes in the tropics are a proxy for deep convection. Figure 10 shows the October through March 19791992 OLR values. The lowest OLR values over land areas in West Africa occur during the months of October and March. Between the months of November and February, the lowest OLR values are displaced westward over the Tropical Atlantic. Typical OLR values of $250-270 \mathrm{~W}-\mathrm{m}^{-2}$ are found over land areas in West Africa from November through February (Figs. 10b-e). Consequently, in order to transport biomass constituents to the middle or upper troposphere, horizontal transport towards the central Atlantic is necessary. Figure 11 shows the precipitation rates over West Africa and the adjacent Atlantic from October through March. Most areas associated with high precipitation rates tend to correspond to those of low OLR values, implying that the precipitation events in the Central Atlantic are associated with 


\section{Zonal mean zonal wind(1979-1992) at $10 \mathrm{~W}$}
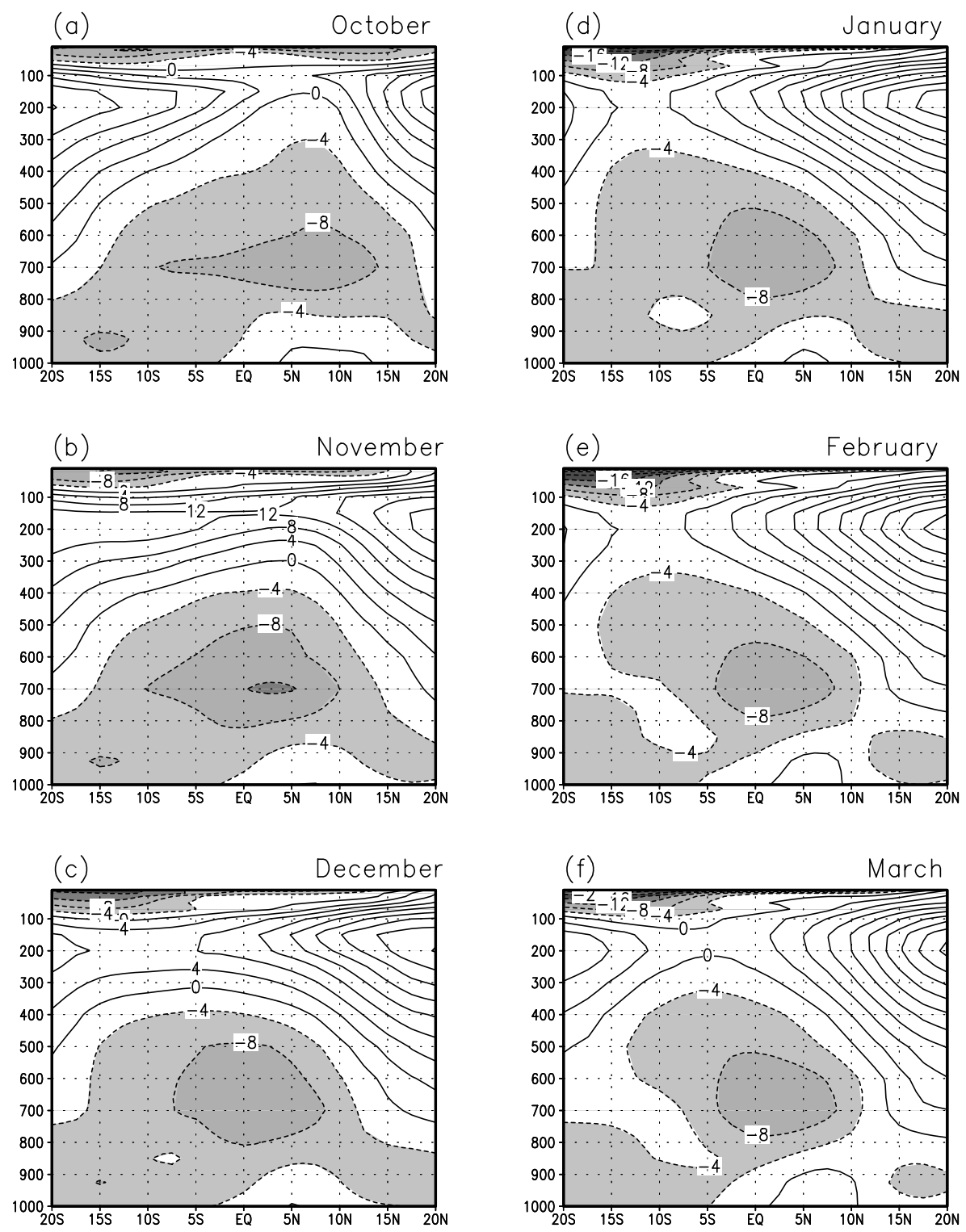

Fig. 9. Vertical Cross section of the climatological zonal wind at $10^{\circ} \mathrm{W}$ for (a) October through (f) March. Units are $\mathrm{m}-\mathrm{s}^{-1}$.

deep convection. The high precipitation rate over Tropical Atlantic Ocean in October shifts to the southwest from October through March.

Low precipitation rates are found over land in southern parts of West Africa from October through November followed by even lower precipitation rates from December through February. Higher precipitation rates are found just equatorward of West Africa in the Gulf of Guinea, but the relatively high OLR values that are found do not imply deep convection. Hence, ozone and ozone precursors from fires that are horizontally transported over the ocean cannot be vertically transported to the middle or upper troposphere by deep convection. Thus, ozone mixing ratios in the lower troposphere can be reduced through photolysis, deposition or may be horizontally transported towards the south or west by low level winds.

If ozone is transported equatorward or to the west by low level winds it could reach the free troposphere over the ocean through adiabatic lifting. In Figs. 12a-c, the time-averaged 1979-1992 north-south cross-sections of 


\section{Outgoing Longwave Radiation (1979-1992)}

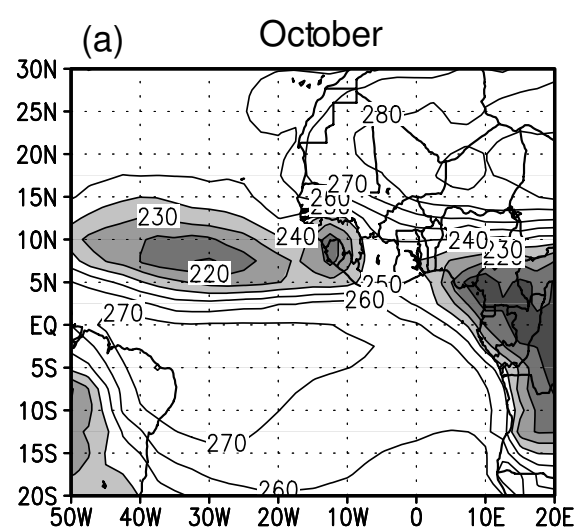

(b)

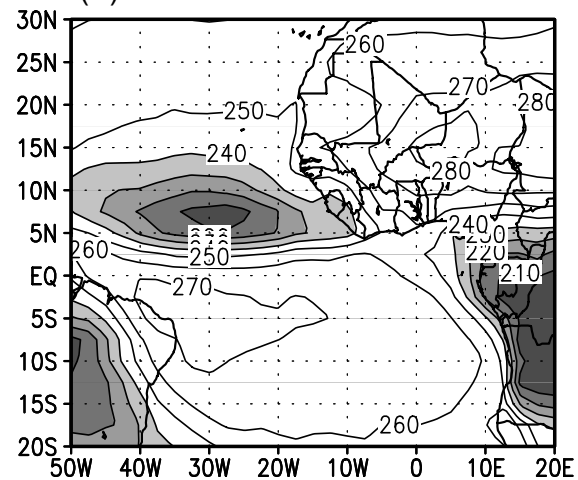

(c)

Deœmber

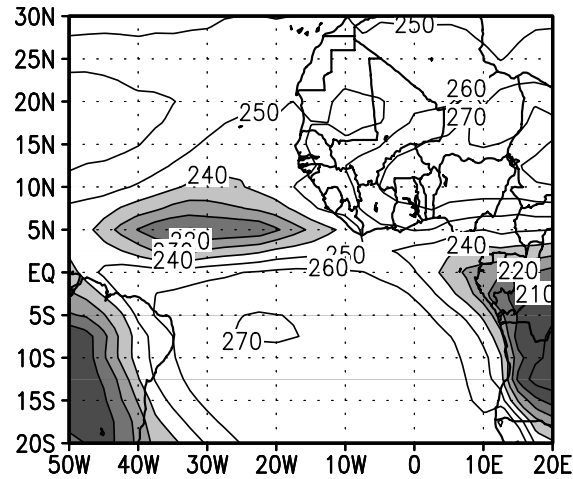

(d) January

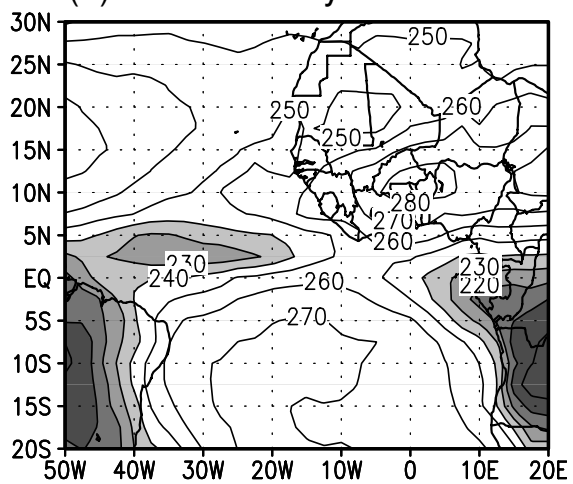

(e)

February

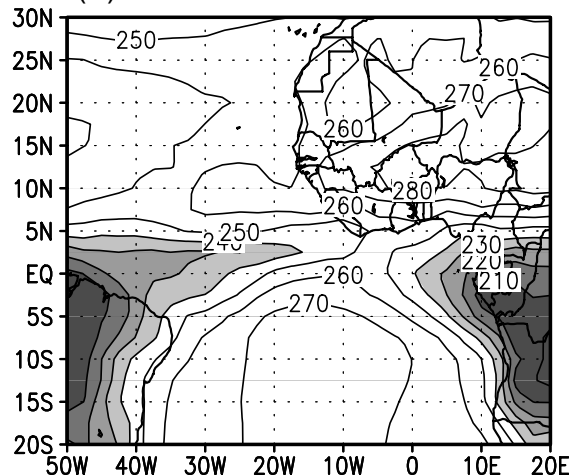

(f)

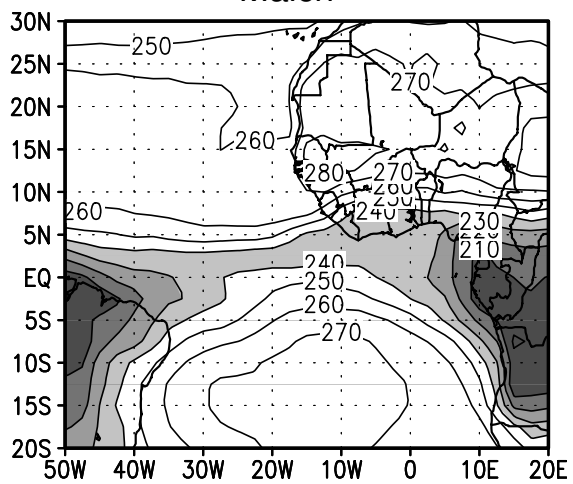

Fig. 10. The climatology of the Outgoing Longwave Radiation (OLR) in West Africa for (a) October through (f) March averaged from 1979 to 1992.

potential temperature at $10^{\circ} \mathrm{W}$ shows that equatorward moving parcels in West Africa near the surface would rise above the marine boundary layer from December through February. Consequently, higher ozone mixing ratios should be found between $950 \mathrm{hPa}$ and $800 \mathrm{hPa}$ in the absence of deep convection over ocean areas due to the equatorward advection of continental air from West Africa. In Figs. 12d-f, the time-averaged 1979-1992 east-west cross-sections of poten- tial temperature at $8^{\circ} \mathrm{N}$ shows that westward moving parcels in West Africa near the surface would rise above the marine boundary layer from December through February. Consequently, higher ozone mixing ratios should be found between $950 \mathrm{hPa}$ and $800 \mathrm{hPa}$ in the absence of deep convection over ocean areas due to the westward advection of continental air from West Africa. These results are in agreement with the equivalent potential temperatures found by Jonquieres 
Precipitation rate $(1979-1992)$

(a) October

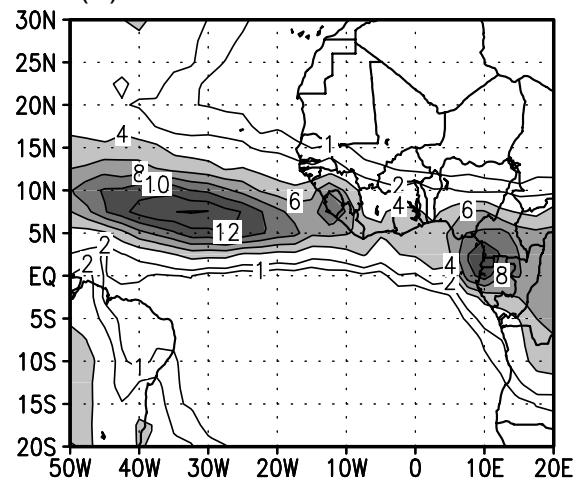

(b)

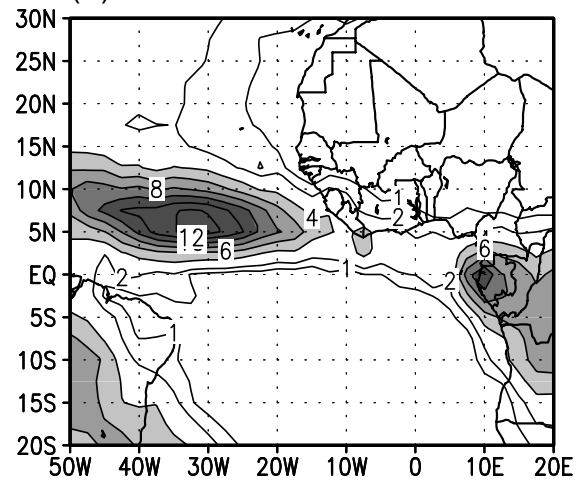

(c) Deœmber

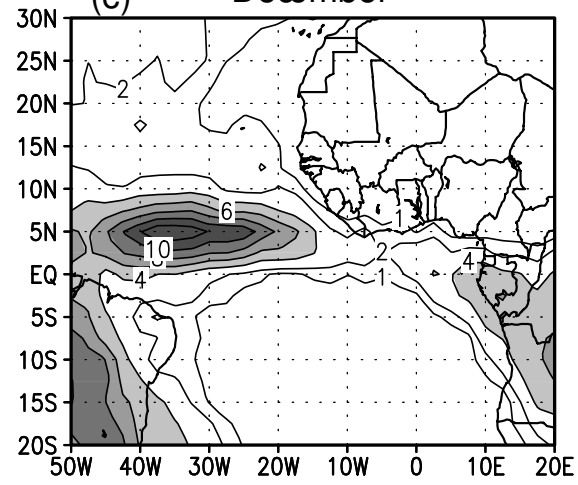

(d) January

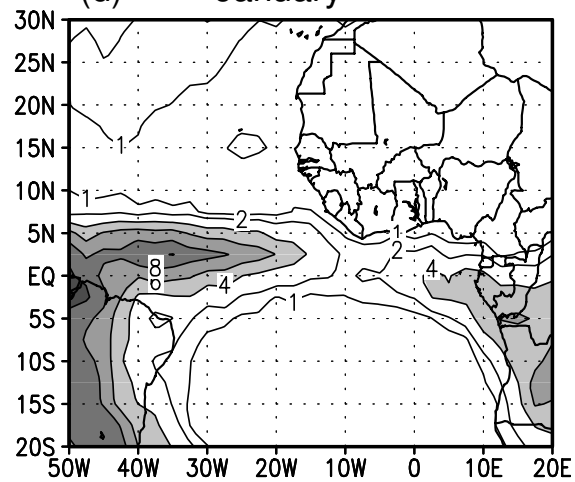

(e) February
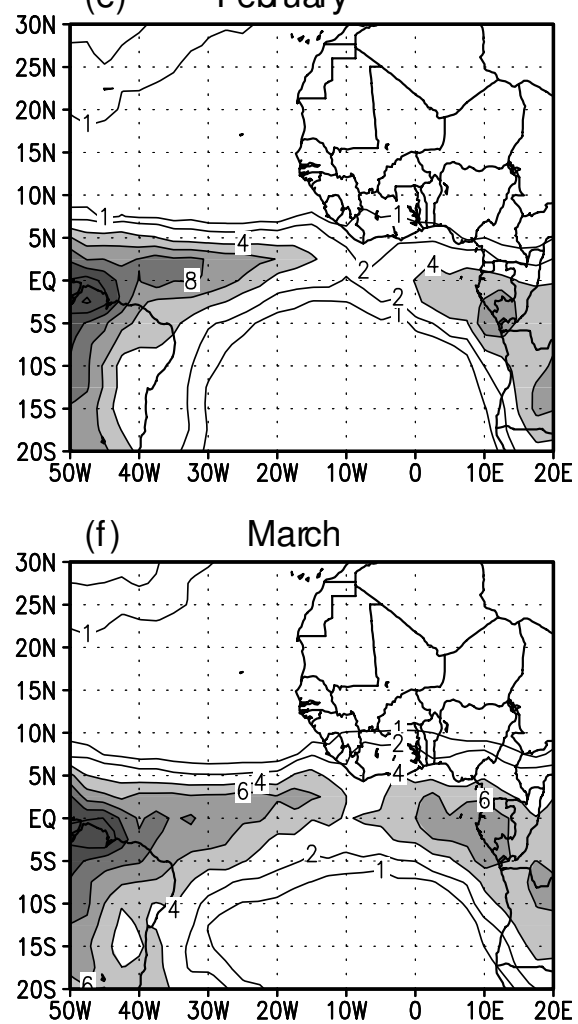

Fig. 11. The climatology of the precipitation rate for (a) October through (f) March averaged from 1979 to 1992 . Units are mm-day $^{-1}$.

et al. (1998) and the $\mathrm{CO}$ and $\mathrm{O}_{3}$ mixing ratios found during flights 10 and 12 during the TROPOZ campaign (CF Plates 1 and 2, Jonquieres et al., 1998). The MOSAIC commercial aircraft measurements also find that that highest ozone mixing ratios near $800 \mathrm{hPa}$ during January of 1997-2000 (Martin et al., 2002).

Lightning can also increase ozone levels through the formation of the ozone precursor, $\mathrm{NO}_{x}$. Aircraft measurements during TRACE-A show elevated $\mathrm{NO}_{x}$ levels in the vicinity of deep convection/lightning (Pickering et al., 1996; Jacob et al., 1996; Smyth et al., 1996). Moreover, the study of Martin et al. (2000) using global lightning $\mathrm{NO}_{x}$ emission estimates available from Price et al. (1997) have found that lightning explains about $20 \%$ of the variance in tropospheric column ozone values using EOF analysis. Figure 13 shows the combined OTD-LIS flash rate ( $\mathrm{fl} / \mathrm{km}^{-2} / \mathrm{dy}$ ) for 2 -month averages from November through February. The lightning distribution shows a strong land bias compared to the OLR distribution (Fig. 10). The high lightning flash rate corresponds to the low OLR over land, while the flash rate is 

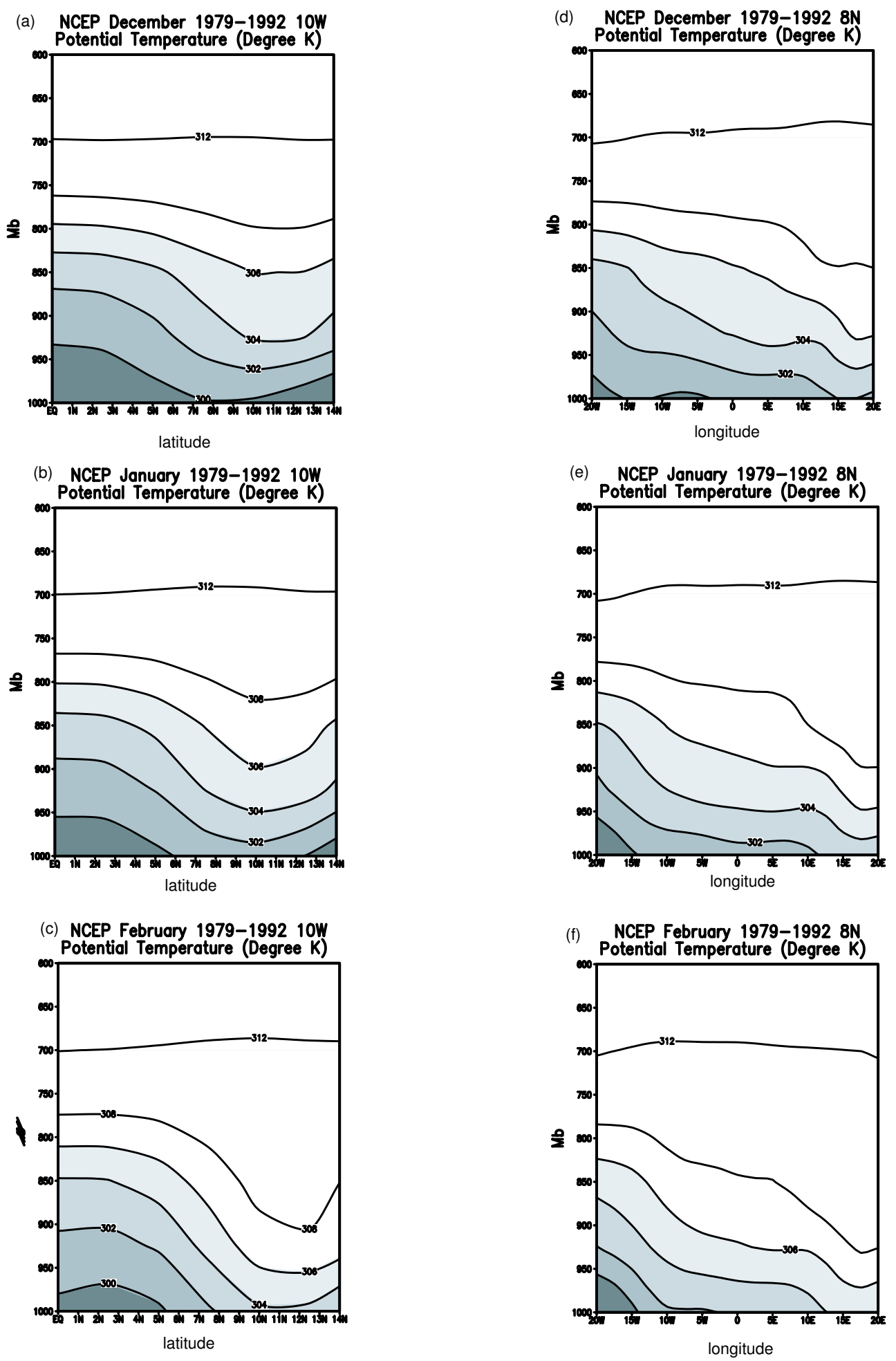

\section{$300 \quad 302 \quad 304 \quad 306$}

Fig. 12. NCEP $1000-600 \mathrm{hPa}$ vertical cross section of Potential Temperatures at $10^{\circ} \mathrm{W}$ for (a) December, (b) January, (c) February and at $8^{\circ} \mathrm{N}$ (d) December, (e) January, (c) February. Units are degree K. 
(a)

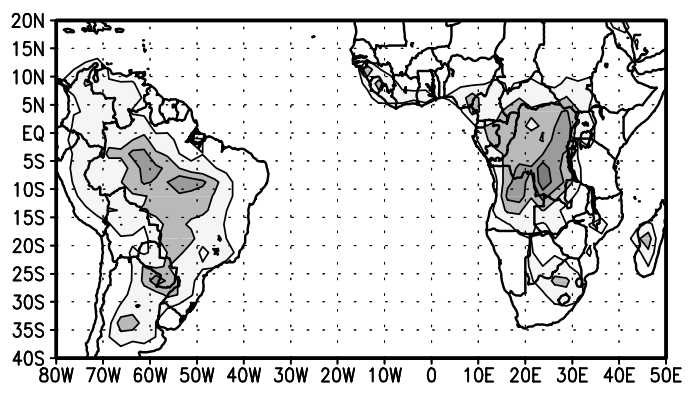

(c)

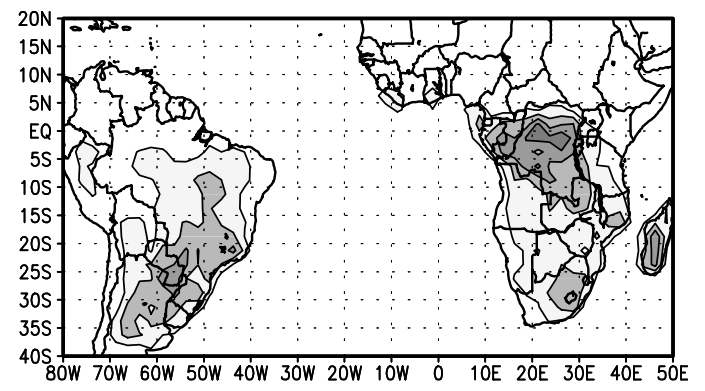

(b)

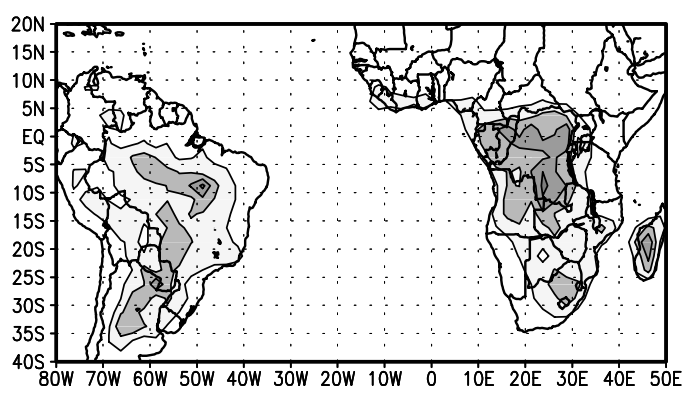

(d)

$$
J A N-F E B
$$

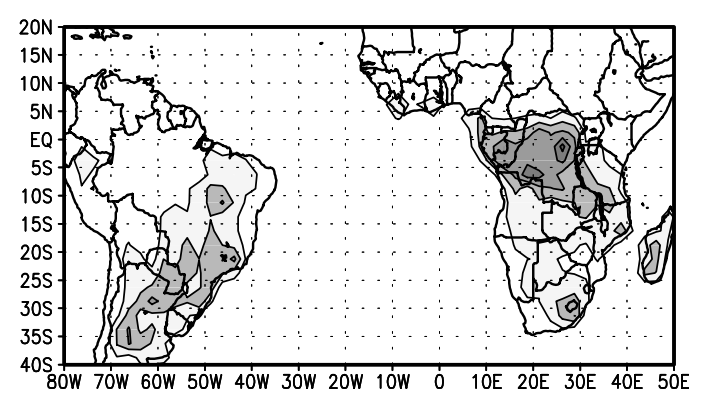

\section{$\begin{array}{lllll}0.05 & 0.1 & 0.15 & 0.2 & 0.25\end{array}$}

Fig. 13. The combined OTD/LIS flash rate for (a) October through (f) March. Units are fl-km ${ }^{-2}-\mathrm{day}^{-1}$.

very small over the tropical Atlantic Ocean even when the OLR values are low. The difference in the spatial distribution of flash rates between tropical oceans and tropical landmasses has been studied by Boccippio et al. (2001), Nesbitt et al. (2000), Toracinta and Zipser (2001). Their studies suggest that land/ocean lightning differences are associated with land versus ocean convective intensity, i.e. the updraft velocity and the cloud optical depth. Warm clouds over the ocean have weaker updrafts and less supercooled liquid water than clouds over land. The weak updrafts reduce the loft of large particles, such as supercooled liquid water, into the mixed phase region causing few ice particle collisions and leading to less charge separation, i.e. less cloud electrification.

High lightning flash rates are found over the continents of Central Africa and South America. Near the coastline of West Africa, lightning is observed during October and November, but the flash rate is reduced December through February. This feature was also shown in Toracinta and Zipser (2001). The lightning frequently occurred over a wide range of the South America continent during October and
November and decreases from December through March. The frequent occurrence of the lightning over the two continents during November through February is likely linked to the elevation of tropospheric column ozone over the Tropical Atlantic Ocean when considering the upper troposphere streamline distribution. During December, an anticyclone whose center is found between $15-20^{\circ} \mathrm{S}$ and near $25^{\circ} \mathrm{E}$ develops and persists through March producing easterly winds and outflow from Central Africa at $200 \mathrm{hPa}$. At the same time, westerly winds are associated with continental outflow from South America at $200 \mathrm{hPa}$ and cyclonic flow over the extreme Western Atlantic. This is essentially a Walker type circulation with rising motions over land and sinking motions over the Tropical Atlantic (not shown). Since both of these regions (Central Africa and South America) are associated with high flash rates, ozone produced by lightning in the upper troposphere would get transported horizontally into the Central Atlantic Ocean producing relatively high ozone values in the latitude band between $10^{\circ} \mathrm{S}$ and $15^{\circ} \mathrm{S}$ during January and February (Figs. 1d, 1e). 


\section{Conclusions}

During Northern Hemisphere autumn, high tropospheric column ozone values ( $>42 \mathrm{DU}$ ) can be found over the Southern Tropical Atlantic Ocean from September through November. During Northern Hemisphere winter (DJF), the highest tropospheric column ozone values are still found over the Southern Tropical Atlantic Ocean and not the Northern Tropical Atlantic Ocean, which is located just downstream of biomass burning in West Africa (Ozone Paradox).

Our analysis suggests that there are four possible processes that can enhance tropospheric ozone levels during N. H. winter over the Tropical Atlantic Ocean.

- Air is transported westward or equatorward from areas of biomass burning near the surface in West Africa is lifted above the marine boundary layer through adiabatic motions even in the absence of moist processes. In this case, the highest concentrations of pollutants should be found between 950 and $800 \mathrm{hPa}$ over the Eastern and Central Atlantic Ocean. Elevated ozone mixing ratios were found in TROPOZ I, II, RV Polarstern and Aerosol99 campaign (Jonquieres et al., 1998; Weller et al., 1996; Thompson et al., 2000).

- Ozone and/or its precursors from biomass burning in West Africa are transported equatorward or westward over the Tropical Atlantic Ocean after it has been vertically transported to the lower/middle troposphere by convection. This process would take place primarily in the Gulf of Guinea where lower OLR and higher precipitation rates are found during the Northern Hemisphere winter season. Even if this process were to occur OLR and precipitation rates do not suggest deep convection and hence ozone or ozone precursors would be detrained in the lower or middle troposphere $(>500 \mathrm{hPa})$ and transported westward over the Tropical Atlantic. At lower pressures $(<500 \mathrm{hPa})$, ozone or ozone precursors would be transported eastward by westerly winds.

- Stratosphere/troposphere exchanges of ozone could also enhance tropospheric columnar levels (Weller et al., 1996). In the tropics, such exchanges would most likely occur with deep convection that penetrates the lower stratosphere (Jenkins et al., 1997). These deep convective systems would be associated with strong vertical updrafts and lightning. The only regions that could be associated with stratosphere/troposphere exchanges would be over Central Africa and parts of South America based on low OLR values and lightning distributions during January.

- The fourth mechanism for enhancing tropospheric ozone especially in the latitude band between $10^{\circ} \mathrm{S}$ and $15^{\circ} \mathrm{S}$ during January and February is associated with
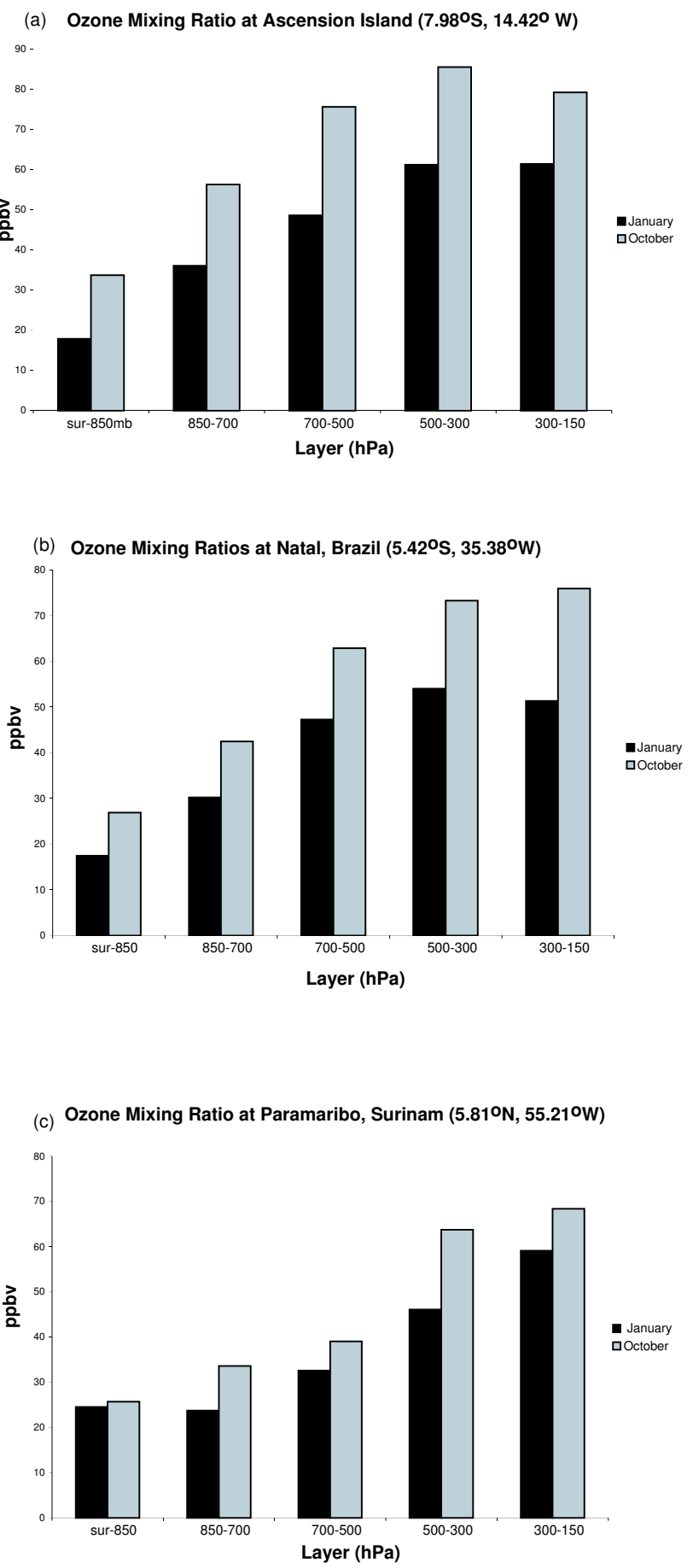

Fig. 14. 1999-2001 ozone mixing ratio during January and October averaged over various tropospheric layers. (a) Ascension Island, (b) Natal, Brazil, (c) Paramaribo, Surinam. Units are in ppbv.

lightning leading to the production of $\mathrm{NO}_{x} / \mathrm{O}_{3}$, and consequently, ozone over Central Africa and South America followed by the horizontal transport of ozone by upper level winds towards the Tropical South Atlantic. Thompson et al. (2000) surmise that ozone production 
of 4-8 DU per day during the Aerosols99 campaign in the upper troposphere was due to $\mathrm{NO}_{x}$ from lightning in Central Africa.

Jonquieres et al. (1998) suggest that elevated $\mathrm{O}_{3}$ levels in the upper troposphere during January were associated with South America. However, they did not provide the mechanism for the production of $\mathrm{O}_{3}$. We have found that the most likely source of $\mathrm{O}_{3}$ is lightning. Thompson et al. (2000) identified lightning from Central Africa as a likely source of elevated ozone in Zone $3\left(0-23^{\circ} \mathrm{S}\right)$. However, our results suggest that upper tropospheric $\mathrm{O}_{3}$ levels in Zone $3\left(0-23^{\circ} \mathrm{S}\right)$ and the southern latitudes of Zone $2\left(14^{\circ} \mathrm{N}-0^{\circ}\right)$ can also be enhanced by lightning from South America. In fact, lightning is probably an important factor in the SON Tropical Atlantic ozone maximum. We examine this possibility further through ozonesonde, lightning data and upper troposphere streamline analysis associated with South America/Central Africa and the Tropical Atlantic.

Figures 14a, b, and c show that the 1999-2001 average ozone mixing ratios at Ascension Island $\left(7.98^{\circ} \mathrm{S}, 14.42^{\circ} \mathrm{W}\right)$, Natal, Brazil $\left(5.42^{\circ} \mathrm{S}, 35.38^{\circ} \mathrm{W}\right)$ and Paramaribo, Surinam $\left(5.81^{\circ} \mathrm{N}, 55.21^{\circ} \mathrm{W}\right)$ are higher in the upper troposphere in both January and October. During January, ozone mixing ratios are approximately $45-65$ ppbv during January in the $500-300 \mathrm{hPa}$ layer and 50-65 ppbv in the 300-150 hPa layer. During October, ozone values in the upper troposphere are enhanced by an additional 5-25 ppbv at the three locations. We believe that the high ozone mixing ratios found at all three sites in the upper troposphere are linked to deep convection/lightning from South America and Central Africa based on our analysis below. Moreover, higher ozone mixing ratios are found at all layers throughout the troposphere during October (Ozone Maximum) relative to January. The 1999-2001 average ozone mixing ratios from the surface to $150 \mathrm{hPa}$ during January at Ascension Island, Natal and Paramaribo are $45 \mathrm{ppbv}, 40 \mathrm{ppbv}$ and $37.1 \mathrm{ppbv}$, respectively. The 1999-2001 average ozone mixing ratios from the surface to $150 \mathrm{hPa}$ during October at Ascension Island, Natal and Paramaribo are 65 ppbv, 56 ppbv and 46 ppbv, respectively.

Figure 15a shows the monthly total number of lightning flashes from the LIS instrument from 1998 through 2001 for a $3^{\circ} \times 3^{\circ}$ area surrounding Natal and Paramaribo. In both cases, only a small number of lightning flashes have been identified near these locations and consequently the $\mathrm{NO}_{x} / \mathrm{O}_{3}$ production by lightning must be transported into this region from other areas of South America. The highest frequency of lightning flashes in Natal occurs during the Southern Hemisphere summer and autumn season and during the Northern Hemisphere summer and autumn seasons at Paramaribo.

Figure 15b shows the 1998-2001 monthly lightning flashes from LIS overpasses for central and northwestern sectors of South America $\left(10^{\circ} \mathrm{N}-10^{\circ} \mathrm{S}, 76^{\circ} \mathrm{W}-56^{\circ} \mathrm{W}\right)$, and over the continental outflow regions of eastern South America $\left(0^{\circ}-20^{\circ} \mathrm{S}, 56^{\circ} \mathrm{W}-36^{\circ} \mathrm{W}\right)$ and Central Africa $\left(4^{\circ} \mathrm{N}-\right.$ $\left.16^{\circ} \mathrm{S}, 9^{\circ} \mathrm{E}-29^{\circ} \mathrm{E}\right)$. Based on the $1998-2001$ period an average of 9206 flashes were detected in Central Africa and 7728 flashes in South America (6164 flashes in central/northwestern and 1564 flashes in eastern parts of South America) during the month of January. Hence, lightning in South America and Central Africa can serve as a source of ozone during January. In contrast, during the same period an average of 26771 lightning flashes were detected during the month of October for the combined three regions. An average of 10637 flashes occurred in Central Africa while 16134 flashes occurred in South America. The large number of lightning flashes in Central Africa and South America overlaps with the timing of the ozone maximum (SON) over the South Tropical Atlantic Ocean. It provides support to the model study by Moxim and Levy (2000), which suggests that the September ozone maximum is due to lightning and not necessarily biomass burning. Model simulations by Martin et al. (2002) show that ozone is enhanced through lightning during DJF and SON by 10-14 DU. Lightning was also suggested as the dominant cause for high NO and ozone values in the upper troposphere during October in TRACE-A experiment (Thompson et al., 1996).

Figures 16 and 17 show the wind patterns in the middle and upper troposphere for January and October 1999-2001. At 500 and $400 \mathrm{hPa}$ during January and October the prevailing winds are easterly and would transport ozone produced by lightning from Central Africa toward the South Tropical Atlantic influencing the 3-ozonesonde stations (Figs. 16, $17 \mathrm{a}, \mathrm{b})$. At $300 \mathrm{hPa}$ during January and October the easterly winds can be found over the Tropical Atlantic, but the easterly winds are displaced into the northern hemisphere during October (Figs. 16c, 17c). The 3-ozonezonde stations are under the influence of $300 \mathrm{hPa}$ easterly winds January but in October only Paramaribo is under the influence of easterly winds. Westerly winds are found above Natal and Ascension Island during October, but an oceanic anticyclone, which circulates air from Central Africa into their vicinities, also influences these stations. During January at $200 \mathrm{hPa}$, Natal and Paramaribo are under the influence of westerly winds from South America while Ascension Island is under the influence from Central Africa (Fig. 16d). During October all three stations are under the influence of westerly winds, which come from South America (Fig. 17d). It is possible that Ascension Island could be influenced by anticyclone flow from Central Africa at $200 \mathrm{hPa}$ in October (Fig. 17d).

A summary of Figs. 14-17 implies that elevated ozone mixing ratios at the 3 ozonesonde stations and over the Tropical Atlantic in the 500-300 hPa layers during January and October are associated with $\mathrm{NO}_{x} / \mathrm{O}_{3}$ produced via lightning processes over Central Africa. Ozone is then transported by easterly winds towards the Tropical South Atlantic and South America. On the other hand, elevated ozone mixing ratios in the 300-150 hPa layers during January and October are associated with $\mathrm{NO}_{x} / \mathrm{O}_{3}$ production via lightning primarily from South America which is transported towards the north and 
(a)

350

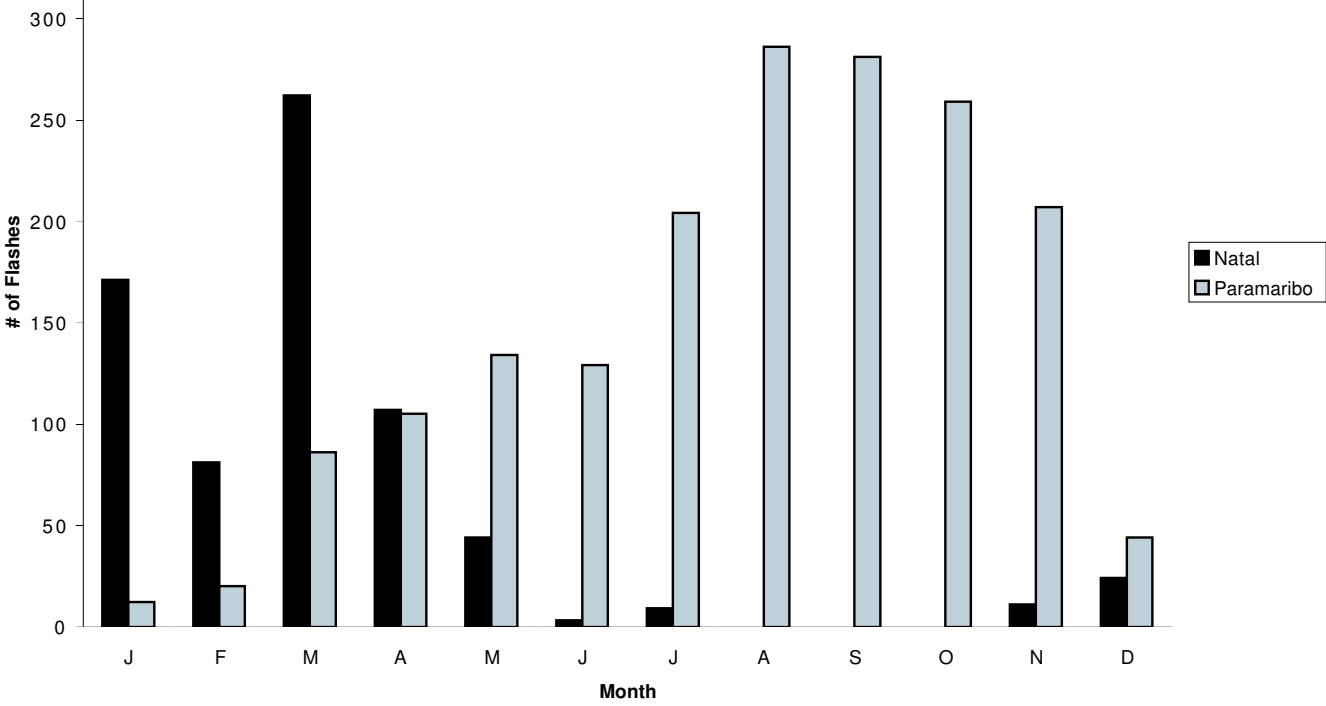

(b)

1998-2001 Total Lightning Flashes

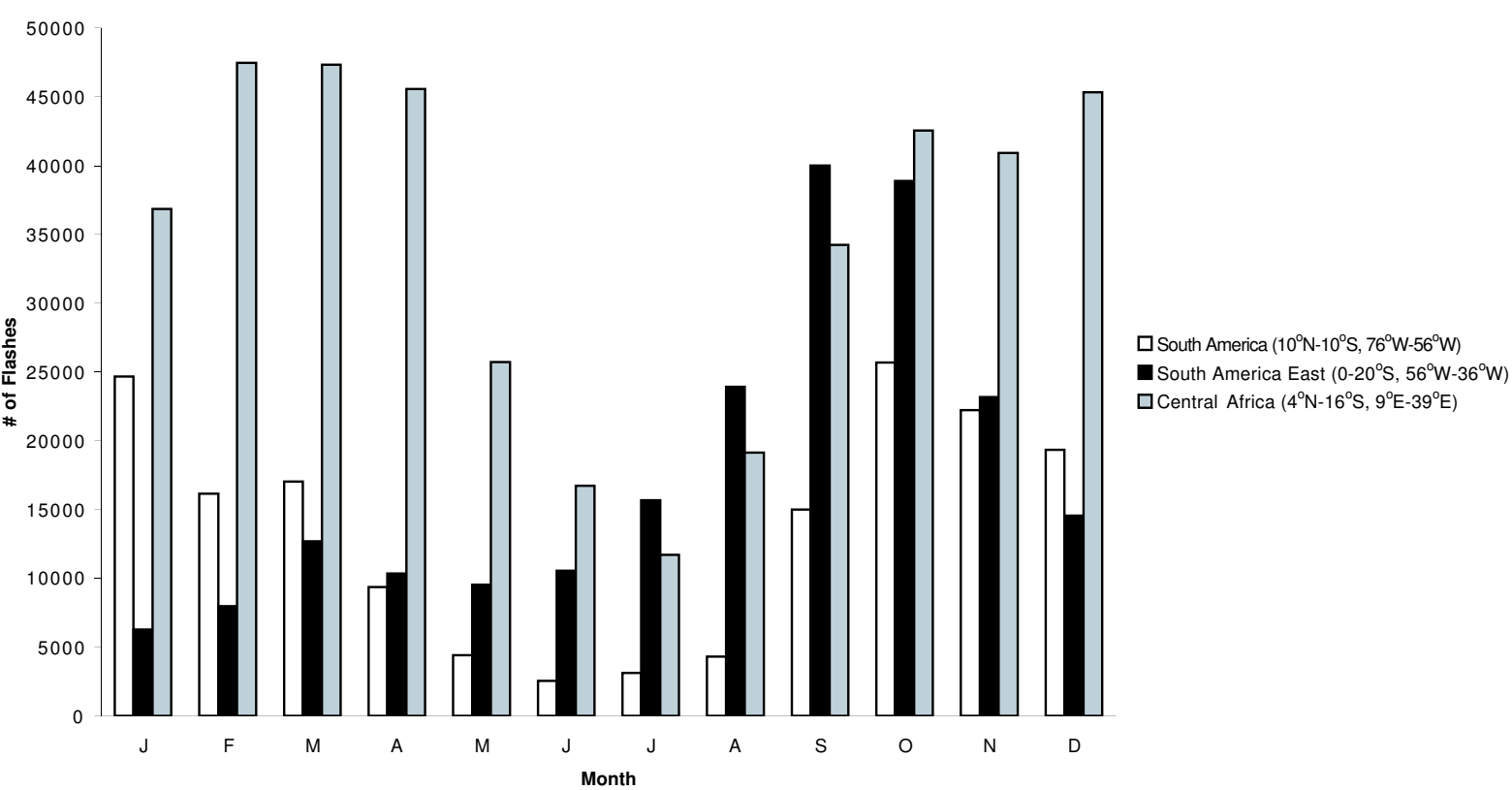

Fig. 15. 1998-2001 total lightning flashes detected by the LIS instrument (a) for Natal, Brazil and Paramaribo, Surinam. (b) For central/northwestern South America, eastern South America and Central Africa. 


Streamline (arrow) and zonal wind (contour)
$1979-1992$
Month $=10 \quad$ Month $=10$

(a)

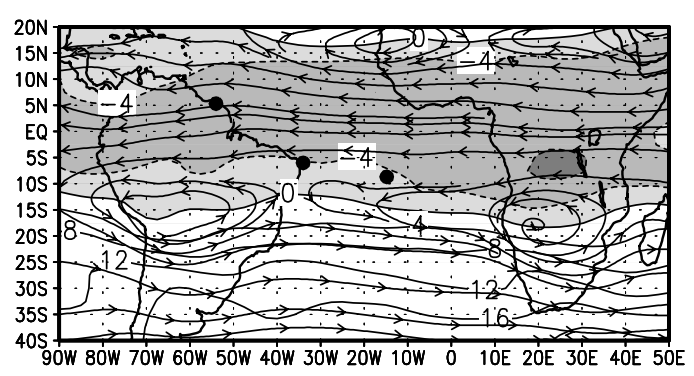

(c)

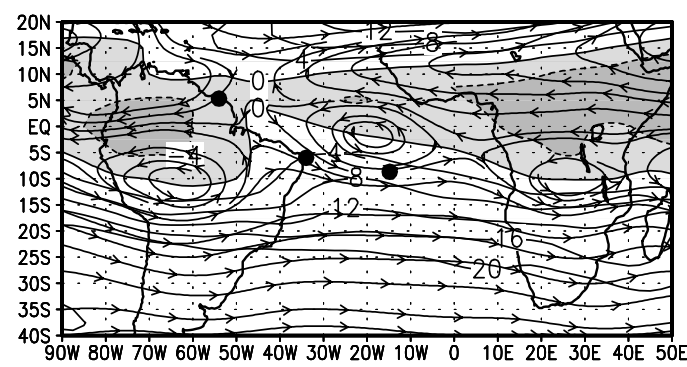

(d) (b)

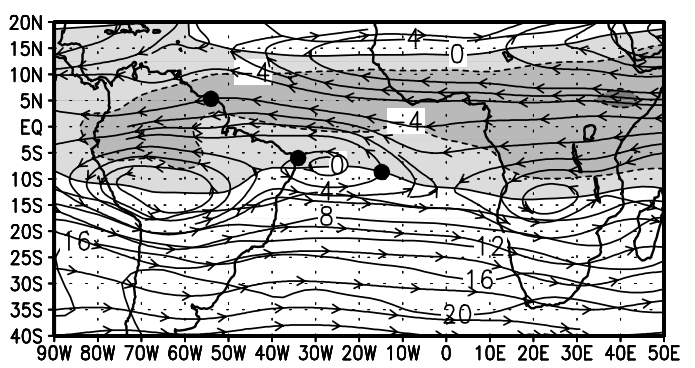

$400 \mathrm{hPa}$

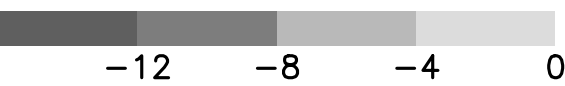

Paramaribo $(5.81 \mathrm{~N}, 55.21 \mathrm{~W})$ Ascension Island (7.98S, 14.42W)

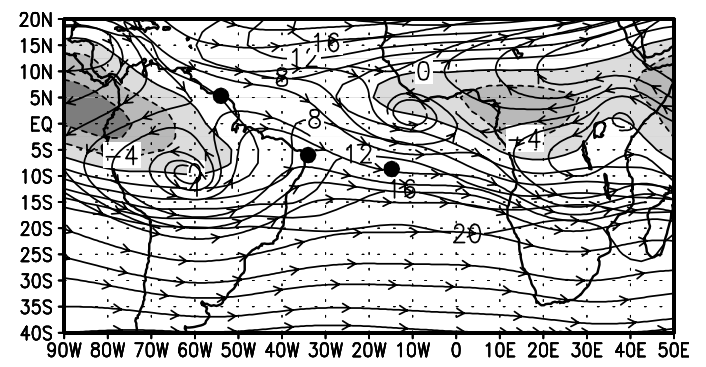
.
Natal (5.42S, 35.38W) 


$$
\begin{gathered}
\text { Streamline (arrow) and zonal wind (contour) } \\
1999-2001 \\
\text { October }
\end{gathered}
$$

(a)

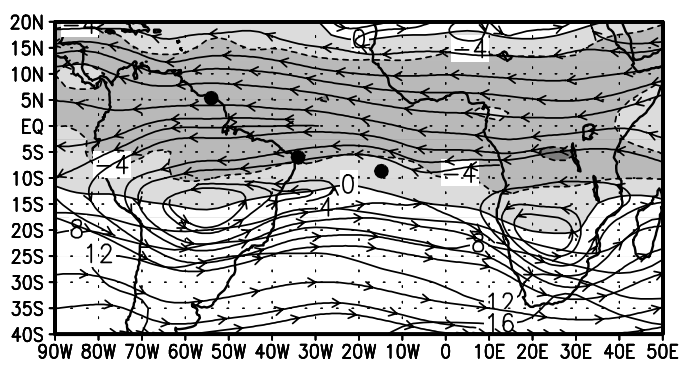

(c)

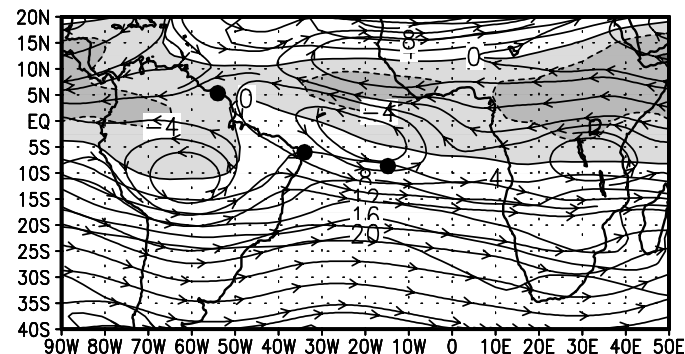

(d)

\section{$200 \mathrm{hPa}$}

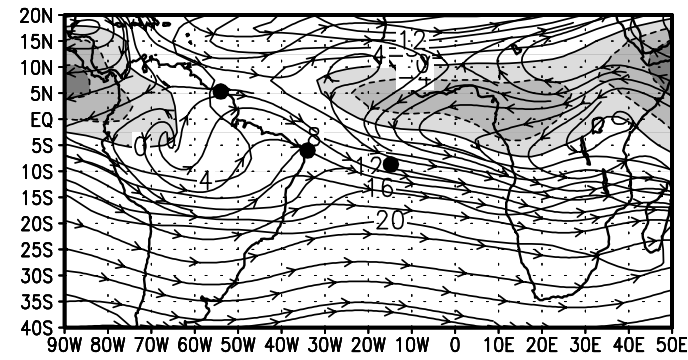

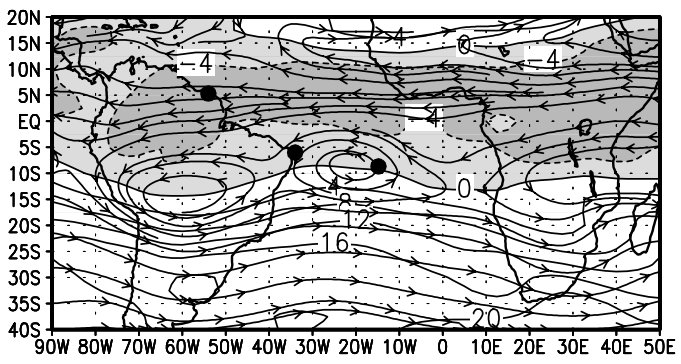

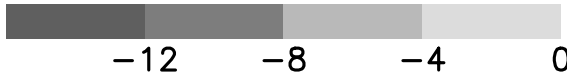

$\begin{array}{llll}-12 & -8 & -4 & 0\end{array}$

Natal (5.42S, 35.38W)

Paramaribo $(5.81 \mathrm{~N}, 55.21 \mathrm{~W})$ Ascension Island (7.98S, 14.42W)

Fig. 17. The climatology of the zonal wind and streamlines at (a) $500 \mathrm{hPa}$, (b) $400 \mathrm{hPa}$, (c) $300 \mathrm{hPa}$ and (d) $200 \mathrm{hPa}$ for SON averaged from 1979 to 1992.

The results presented here are also consistent with the results of Jenkins et al. (2003) for the Aerosols99 campaign time period. We have shown Jenkins et al. (2003), however, that on daily-time scales eastward propagating anti-cyclones in the middle/upper troposphere can influence the horizontal transport (trajectories) and convection in the Gulf of Guinea may lead the vertical transport of ozone/ozone precursors associated with biomass burning in West Africa. We have also shown that for this time period that lightning in Gulf of Guinea, Central Africa and South America influenced the measured ozone in the middle/upper troposphere. Because of westerly wind at high altitudes, lightning over South America can influence ozone mixing ratios at pressure levels less than $300 \mathrm{hPa}$, while lightning over Central Africa influences ozone mixing ratios in the middle troposphere $(500 / 300 \mathrm{hPa})$.
Future field experiments should be undertaken over the Tropical Atlantic $\left(20^{\circ} \mathrm{N}-20^{\circ} \mathrm{S}\right)$, adjacent South American and West African land masses to determine the various sources (biomass burning, lightning), sinks (photolysis, deposition), horizontal and vertical transports (convection). One important issue to resolve is the differences between TOMS satellite derived tropospheric column ozone values and those of ozonesondes. The proposed African Monsoon Multidisciplinary Experiment (AMMA), which has a winter monsoon component (http://medias.obs-mip.fr/amma) could help to resolve some of these issues. However, long-term monitoring sites of ozone in West Africa will provide a more complete understanding of the ozone paradox with the other monitoring sites in the Southern Hemisphere tropics (Logan, 1999). 
Acknowledgements. This research was supported through NSF Grant ATM-0105206 and NASA Grant NAG5-7443. Lightning data have been provided by the NASA Lightning Imaging Sensor (LIS) science team and the LIS data center located at the Global Hydrology and Climate Center (GHCC), Huntsville, Alabama. NCEP data have been provided by the climate diagnostics center in Boulder Colorado. We thank T. Stoy for the useful comments on this manuscript.

Edited by: P. Monks

\section{References}

Arino, O. and Melinotte, J.-M.: The Fire Atlas, Earth Observation Quarterly, 50, December, 1995.

Andreae, M.: Biomass burning: Its history, use and distribution and its impact on environmental quality and global climate, Global Biomass Burning: Atmospheric, Climatic and Biospheric Implications, edited by Levine, J. S., pp. 3-21, MIT Press, Cambridge, Mass., 1991.

Boccippio, D. J., Goodman, S. J., and Heckman, S.: Regional differences in tropical lightning distribution, J. Appl. Met., 39, 2231-2248, 2000.

Buongiorno, A., Arino, O., Zehner, C., Colagrande, P., and Goryl, P.: ERS-2 Monitors The South East Asia Exceptional Fire Event, Earth Observation Quarterly, 56, 1997.

Christian, H. J., Blakeslee, R. J., Boccippio, D. J., et al.: Global frequency and distribution of lightning as observed from space by the Optical Transient Detector, J. Geophys. Res., 108, doi:10.1029/2002JD002347, 2003.

Cooke, H. K.: Generation of the African easterly jet and its role in determining West African Precipitation, J. Climate, 12, 11651184, 1999.

Crutzen, P. J. and Carmichael, R.: Modeling the influence of fires on atmospheric chemistry, Fire in the Environment: The ecological and Climatic Influence of Vegetation Fires, edited by Crutzen, P. J. and Goldhammer, J. G., John Wiley, NY, 1993.

Edwards, D. P., Lamarque, J.-F., Attie, J.-L., et al.: Tropospheric Ozone over the Tropical Atlantic: A satellite perspective, J. Geophys. Res., 108, doi:10.1029/2002JD002927, 2003.

Fishman, J., Fakhruzzaman, K., Cros, B., and Nganga, D.: Identification of Widespread Pollution in the Southern Hemisphere Deduced from Satellite Analyses, Science, 252, 1693-1696, 1991.

Fishman, J., Hoell Jr., J. M., Bendura, R. D., McNeal, R. J., and Kirchhoff, V. W. J. H.: NASA GTE TRACE A Experiment (September-October 1992): Overview, J. Geophys. Res., 101, 23 865-23 879, 1996.

Grégoire, J.-M., Pinnock, S., Dwyer, E., and Janodet, E.: Satellite monitoring of vegetation fires for EXPRESSO: Outline of activity and relative importance of the study area in the global picture of biomass burning, J. Geophys. Res., 104, 30 691-30 699, 1999.

Herman, J. R., Bhartia, P. K., Torres, O., Hsu, C., Seftor, C., and Celarier, E.: Global Distribution of UV-Absorbing Aerosols From Nimbus-7/TOMS Data, J. Geophys. Res., 102, 16911$16922,1997$.

Hudson, R. D. and Thompson, A. M.: Tropical tropospheric ozone from total ozone mapping spectrometer by a modified-residual method, J. Geophys. Res., 103, 22 129-22 145, 1998.
Jacob, D. J., Heikes, B. G., Fan, S.-M., et al.: Origin of ozone and NOx in the tropical troposphere: A photochemical analysis of aircraft observations over the South Atlantic basin, J. Geophys. Res., 101, 24 069-24 082, 1996.

Jenkins, G. S., Mohr, K., Morris, V. R., and Arino, O.: The Role of Convective Processes over the Zaire and Congo Basins to the Southern Hemisphere Ozone Maximum, J. Geophys. Res., 102, 18 963-18 980, 1997.

Jenkins, G. S., Ryu, J.-H., Thompson, A., and Witte, J.: Linking horizontal and vertical transports of biomass fire emissions to the Tropical Atlantic Ozone Paradox during the Northern Hemisphere winter season: 1999, J. Geophys. Res., doi:10.1029/JD2002003297, 2003.

Jonquieres, I., Marenco, A., Maahes, A., and Rohrer, F.: Study of Ozone Formation and TransAtlantic Transport from Biomass Burning Emissions over West Africa during the Airborne Tropospheric Ozone Campaigns TROPOZ I and TROPOZ II, J. Geophys. Res., 103, 19059-19073, 1998.

Kalnay, E., Kanamitsu, M., Kistler, R., et al.: The NCEP/NCAR 40-Year Reanalysis Project, Bulletin of the American Meteorological Society, 77, 3, 437-472, 1996.

Kim, J. H., Newchurch, M. J., and Han, K.: Distribution of Tropical Ozone Determined by the Scale-Angle Method Applied to TOMS Measurements, JAS, 58, 2699-2708, 2001.

Lacaux, J. P., Cachier, H., and Delmas, R. A.: Biomass Burning in Africa: An overview of its impact on atmospheric chemistry in Fire in the Environment: The ecological and Climatic Influence of Vegetation Fires, edited by Crutzen, P. J. and Goldhammer, J. G., John Wiley, NY, 1993.

Lindesay, J. A., Andreae, M. O., Goldammer, J. G., et al.: International Geosphere-Biosphere Programme/International Global Atmospheric Chemistry SAFARI-92 field experiment: Background and overview, J. Geophys. Res., 101, 23 521-23 530, 1996.

Logan, J. A.: An analysis of ozonesonde data for the troposphere: Recommendations for testing 3-D models and development of a gridded climatology for tropospheric ozone, J. Geophys. Res., 104, 16 115-16 149, 1999.

Martin, R. V., Jacob, D. J., Logan, J. A., et al.: Detection of a lightning influence on tropical tropospheric ozone, Geophys. Res. Lett., 27, 1639-1642, 2000.

Martin, R. V., Jacob, D. J., Logan J. A., et al.: Interpretation of TOMS observations of tropical tropospheric ozone with a global model and in situ observations, J. Geophys. Res., 107, doi:10.1029/2001JD001480, 2002.

Marufu, L., Dentener, F., Lelieveld, J., Andrea, M. O., and Helas, G.: Photochemistry of the African troposphere: Influence of biomass-burning emissions, J. Geophys. Res., 105, $14513-$ 14530, 2000.

Moxim, W. J. and Levy II, H.: A model analysis of the tropical South Atlantic Ocean tropospheric ozone maximum: The interaction of transport and chemistry, J. Geophys. Res., 105, 17393 $17415,2000$.

Nesbitt, S. W., Zipser, E. J., and Cecil, D. J.: A census of precipitation features in the tropics using TRMM: Radar, ice scattering and lightning observations, J. Clim, 13, 4087-4106, 2000.

Pickering, K. E., Thompson, A. M., Wang, Y., et al.: Convective transport of biomass burning emissions over Brazil during TRACE-A, J. Geophys. Res., 101, 23 993-24 012, 1996. 
Price, C., Penner, J., and Prather, M.: NOX from lightning 1. Global distribution based on lightning physics, J. Geophys. Res., 102, 5929-5941, 1997.

Smyth, S. B., Sandholm, S. T., Bradshaw, J. D., et al.: Factors influencing the upper free tropospheric distribution of reactive nitrogen over the South Atlantic during the TRACE A experiment, J. Geophys. Res., 101, 24 165-24 186, 1996.

Thompson, A. M., Pickering, K. E., McNamara D. P., et al.: Where did tropospheric ozone over southern Africa and the tropical Atlantic come from in October 1992? Insights from TOMS, GTE TRACE A, and SAFARI 1992, J. Geophys. Res., 101, 24 251$24278,1996$.

Thompson, A. M. and Hudson, R. D.: Tropical tropospospheric (TTO) maps from Nimbus 7 and Earth-Probe TOMS by the Modified-Residual method: Evaluation with sondes, ENSO signals and trends from Atlantic regional time series, J. Geophys. Res., 104, 26961-26975, 1999.

Thompson A. M., Doddridge, B. G., Witte, J. C., et al.: A Tropical Atlantic Paradox: Shipboard and Satellite Views of a Tropospheric Ozone Maximum and Wave-one in January-February 1999, Geophys. Res. Lett., 27, 3317-3320, 2000.

Thompson, A. M., Witte, J. C., McPeters, R. D. et al.: Southern Hemisphere Additional Ozonesondes (SHADOZ) 19982000 tropical ozone climatology 1. Comparison with Total Ozone Mapping Spectrometer (TOMS) and ground-based measurements, J. Geophys. Res., 108, DOI:10.1029/2001JD000967, 2003.
Toracinta, E. R. and Zipser, E. J.: Lightning and SSM/I icescattering mesoscale convective systems in the global tropics, J. Appl. Met., 40, 983-1002, 2001.

Torres, O., Bhartia, P. K., Herman, J. R., Ahmad, Z., and Gleason, $\mathrm{J}$.: Derivation of aerosol properties from satellite measurements of backscattered ultraviolet radiation: Theoretical basis, J. Geophys. Res., 103, 17 099-17 110, 1998.

Weller, R., Lilischkis, R., Schrems, O., Neuber, R., and Wessel, S.: Vertical ozone distribution in the marine atmosphere over the central Atlantic Ocean ( $\left.56^{\circ} \mathrm{S}-50^{\circ} \mathrm{N}\right)$, J. Geophys. Res., 101, 1387-1399, 1996.

Williams, E. R., Rothkin, K., Stevenson, D., and Boccippio, D. J.: Global lightning variations caused by changes in thunderstorm flash rate and by changes in the number of thunderstorms, J. Appl. Met. 39, 2223-2230, 2000.

Xie, P. and Arkin, P. A.: Global Precipitation: 17-Year Monthly Analysis Based on Gauge Observations, Satellites Estimates and Numerical Model Outputs, BAMS, 78, 2539-2558, 1997.

Ziemke, J. R., Chandra, S., and Bhartia, P. K.: "Cloud Slicing": A new technique to derive upper tropospheric ozone from satellite measurements, J. Geophys. Res., 106, 9853-9867, 2001. 